\title{
THE IMPACT OF CHANGING EARNINGS VOLATILITY ON RETIREMENT WEALTH
}

\author{
Austin Nichols and Melissa M. Favreault
}

CRR WP 2008-14

Released: December 2008

Date Submitted: October 2008

\author{
Center for Retirement Research at Boston College \\ Hovey House \\ 140 Commonwealth Avenue \\ Chestnut Hill, MA 02467
}

Tel: 617-552-1762 Fax: 617-552-0191

The research reported herein was pursuant to a grant from the U.S. Social Security Administration (SSA) funded as part of the Retirement Research Consortium (RRC). The findings and conclusions expressed are solely those of the authors and do not represent the views of SSA, any agency of the Federal Government, the RRC, Boston College, or The Urban Institute. We thank Seth Zimmerman for research assistance. Thomas DeLeire, John Laitner, and Jonathan Schwabish provided helpful comments on an earlier draft.

(C) 2008, by Austin Nichols and Melissa M. Favreault. All rights reserved. Short sections of text, not to exceed two paragraphs, may be quoted without explicit permission provided that full credit, including (C) notice, is given to the source. 


\title{
About the Center for Retirement Research
}

The Center for Retirement Research at Boston College, part of a consortium that includes parallel centers at the University of Michigan and the National Bureau of Economic Research, was established in 1998 through a grant from the Social Security

Administration. The Center's mission is to produce first-class research and forge a strong link between the academic community and decision makers in the public and private sectors around an issue of critical importance to the nation's future. To achieve this mission, the Center sponsors a wide variety of research projects, transmits new findings to a broad audience, trains new scholars, and broadens access to valuable data sources.

\author{
Center for Retirement Research at Boston College \\ Hovey House \\ 140 Commonwealth Avenue \\ Chestnut Hill, MA 02467 \\ phone: 617-552-1762 fax: 617-552-0191 \\ e-mail: crr@bc.edu \\ www.bc.edu/crr
}

Affiliated Institutions:

The Brookings Institution

Massachusetts Institute of Technology

Syracuse University

Urban Institute 


\begin{abstract}
Over the last several decades, the volatility of family income has increased markedly, and own earnings volatility has remained relatively flat. Volatility may affect retirement wealth, depending on whether volatility affects accrued pension contributions or withdrawals or earnings credited toward future Social Security benefits. This project assesses the effect of the volatility of individual and family earnings on asset accumulation and projected retirement wealth using survey data matched to administrative earnings records.
\end{abstract}




\section{Introduction}

Over the last several decades, the volatility of family income has increased markedly, and own earnings volatility has remained relatively flat (Nichols and Zimmerman 2008). Volatility may affect retirement wealth, depending on whether volatility affects accrued pension contributions or withdrawals or earnings credited toward future Social Security benefits, and on how individuals respond to changing volatility. This project assesses the effect of the volatility of individual and family earnings on asset accumulation and projected retirement wealth using survey data matched to administrative earnings records.

We examine the effect of changing earnings volatility on accumulated net assets at retirement age, including the present discounted value of expected Social Security OldAge and Survivor's Insurance (OASI) benefits. Several researchers have found large changes in the "transitory variance" or "volatility" of earnings from year to year around a longer-term earnings trajectory. Volatility of own earnings appears to have varied with the business cycle for the last four decades while the volatility of family earnings has risen substantially over time, perhaps doubling over the 1980s and 1990s. Much of this analysis has looked at annual means across individuals, but the impact of this volatility at the individual level may be quite heterogeneous, and for various reasons may have substantial effects on assets at retirement age.

The project addresses the following research questions:

- How does earnings volatility affect the ability to save for retirement?

- How well does the Social Security system insure against earnings volatility?

Earnings volatility may force individuals to save in lower-earning, more liquid accounts in order to smooth consumption over time. Higher volatility may also force more dissavings in any given year, and both of these factors may lead to lower well-being in retirement. On the other hand, individuals may trade off higher mean earnings against increased volatility, so if workers are compensated to some degree for accepting higher risk in earnings by earning greater returns, the impact of increased volatility on wealth is ambiguous. In addition, individuals and families who have higher wealth may be more prepared to take on additional risk in their earnings. 
We are also interested in whether Social Security rules protect people's retirement wealth from earnings volatility. For example, the progressive structure of the Social Security replacement rate may smooth differences across individuals or across time in earnings volatility, but wage indexing, incomplete Social Security coverage, and the top35 rule may have different effects. The taxable maximum in earnings also acts to lower Social Security wealth for some with high earnings volatility, since two years of earnings above and below the taxable maximum by the same amount produce a lower benefit than two years at the taxable maximum. Changing patterns of earnings volatility may have very different effects on Social Security wealth for couples than individuals, because offsetting labor market behavior of husbands and wives may explain some of the increasing family earnings volatility. Further, Social Security provides additional benefits to workers' spouses and survivors at no additional cost, leading to varied patterns of redistribution among couples with different earnings patterns (see, for example, Favreault et al. 2002).

\section{Contribution to the literature and policy relevance}

Income/earnings volatility refers to changes in an individual's or family's income/earnings over some time interval. Changes can result from a wide range of circumstances, some voluntary and some involuntary, some temporary and some permanent. Negative employment or family shocks, for example reductions in family hours worked (including reduction to zero) because of a plant closing or other job loss, disability, or an unanticipated loss of a spouse (due to divorce or early widowhood) may be the first thing that comes to mind for many when thinking about earnings or income volatility. But volatility also reflects “positive” shocks, like bonuses, raises, or increased overtime pay. It reflects noisiness in economic outcomes because of variation in the cyclical dependence of wages/earnings across occupations and industries (for example, construction workers' and stockbrokers' wages are more volatile than those of government workers or health care technicians) and even within them. It can also reflect key family investments, like the choice to have one spouse forgo paid work for a while to invest in his/her own education or in the care and education of a couple's children. 
Several authors have noted the apparent increase in volatility in family income, for example, Gottschalk et al. (1994), Moffitt and Gottschalk (2002), Gosselin (2004, 2008), Hacker (2006), Dynan et al. (2007), and Nichols and Zimmerman (2008). ${ }^{1}$ CBO (2007) and CBO (2008) offer a competing perspective, claiming that volatility is largely unchanged since 1980. We address this literature, but move beyond it to examine a potential consequence of volatility for economic well-being in retirement. The insurance value of Social Security is not just insurance against running out of assets in old age, or losing income when a provider dies-OASI can also insure the lifetime income of individuals and families. If much of an observed increase in income volatility were offset by changes in Social Security wealth, and a net rise in income volatility is undesirable, that may argue for not cutting OASI benefits to ensure solvency, unless another form of volatility insurance became available (whose cost would need to be estimated). One recent study considered the effects of negative pre-retirement shocks on retirement wealth (Johnson, Mermin, and Murphy 2007). Because volatility encompasses a far wider spectrum of changes, including positive ones, our question is thus distinct and worthy of independent analysis.

The empirical analysis which comes closest to ours is Mitchell, Phillips, Au, and McCarthy (2007). Mitchell et al. use the Health and Retirement Study (HRS) matched to Social Security Administration earnings data to consider the effects of long-term earnings variability (specifically, the coefficient of variation—or ratio of the standard deviation to the mean--for earnings between the $20^{\text {th }}$ and $50^{\text {th }}$ birthdays, with additional analyses looking at the effects in each decade) on various forms of wealth. They test for asymmetric aspects of volatility (analogous to the "negative shocks" concept discussed above). They find that non-married people are more sensitive to volatility than married people and that different types of wealth are associated with volatility in different ways.

While there are many similarities (similar exploration of different wealth variables, disaggregation of households by marital status), our work differs from this prior study in several key ways. First, we supplement HRS data with data from another

\footnotetext{
${ }^{1}$ Explanations for the change in volatility are wide-ranging, and include globalization of labor and capital markets, the effects of government policy (e.g., declining regulation), declining unionization, changing norms about permissible variation in compensation within firms, increased efficiency of the labor market at rewarding outstanding innovations, high levels of immigration, and other factors
} 
matched survey, enabling us to check robustness and follow cohorts over a longer time period. Second, we focus more on shorter-term volatility. Further, we decompose the effect of volatility into two parts: the level and the change. This allows us to consider the independent effects of changes in the larger economic environment. Finally, we also compare to instrumental variables estimates to evaluate whether observed effects of increased volatility (due to selection, results of choices made by workers, and exogenous factors like labor market conditions) are similar to the causal effects of exogenous shifts in volatility, and find that they are, for the most part.

Our exercise is primarily descriptive and empirical. There is a vast literature on the relationship between earnings uncertainty and volatility and savings that provides an important theoretical context for this work (for example, Hubbard 1985, 1987, Hubbard and Judd 1987, Hubbard, Skinner, and Zeldes 1994, 1995, Parker, Barmby and Belghitar 2005).

\section{Methods}

We begin by documenting earnings volatility, first computing the estimated variance of earnings within a moving window of years, and then describing how mean and median volatility (measured across individuals) have evolved over time. We also describe how volatility varies across groups, between couples and never married people, and across cohorts. We also compare the distribution of wealth, both total net worth and net housing equity, and Social Security wealth (projected total lifetime benefits payable based on earnings histories). All dollar values are measured in 2000 dollars, deflated by the research series of the Consumer Price Index for all urban consumers.

We calculate volatility as the variability in summed annual earnings of husband and wife, or own earnings for never-married individuals. We use regression analysis to relate Social Security wealth and other wealth to volatility, estimating wealth levels as a function of earnings volatility in one set of models, and the level and change in volatility in another set, conditional on other characteristics. Different components of net worth, including net financial assets and home equity, and Social Security wealth, are the dependent variables in these regressions, and volatility measures are explanatory variables. Social Security wealth is defined at every point in time as the present 
discounted value (PDV) of the OASDI benefit to be received at modal retirement age, and we measure Social Security wealth for each individual at the last point in time that we observe other assets. Control variables in the analyses include demographic categories such as age, sex, education, and earnings.

\section{Data}

We use data from two longitudinal surveys, both of which have been matched to administrative earnings records. The first is the 1990, 1991, 1992, 1993, 1996, and 2004 panels of the Survey of Income and Program Participation (SIPP) matched to Detailed Earnings Records (DER) where available, and Summary Earnings Records (SER) elsewhere, and also to the Master Beneficiary Records (MBR) to supply accurate program participation information. The SIPP represents the non-institutional population and oversamples lower-income households likely to participate in transfer programs. Its panels are relatively short (with a maximum four years in duration), but with frequent interviews (every four months). The second survey is the Health and Retirement Study (HRS) matched to DER and SER data, and the MBR. HRS focuses on older adults approaching retirement age (sampling those aged 51 to 61 in 1992, 1998, and 2004), and oversamples blacks, Hispanics, and Florida residents. Its panels are longer than SIPP's (still on-going, with the original panel now 16 years into the follow-up period), though interviews are less frequent (every two years). We focus on those who are interviewed in the HRS in $1998 .^{2}$ We weight all of our estimates and adjust the standard errors for clustering due to the complex sample designs of the two surveys.

The SER, which includes earnings reports from 1951 through the date of most recent data extraction (ranging from 1992 through 2006 in the various surveys we use), reports earnings that the Social Security program covers up through the program's wage and benefit base, also known as the taxable maximum, set at $\$ 102,000$ in $2008 .{ }^{3}$ It thus is

\footnotetext{
2 The HRS matches to the administrative data differ from the SIPP match insofar as the SIPP matches are updated regularly (roughly annually), while the HRS match has only been drawn twice, once in 1992 (or 1999 for the War Babies cohort) and then again in 2004 (with data from an additional match based on 2006 permissions forthcoming according to the HRS website). Individuals need to have given permission separately at each point to be included in that match.

${ }^{3}$ Certain sectors of the labor force, including state workers who are covered by state pensions in select states, certain students, and federal workers hired prior to January 1, 1984, are exempt from paying Social
} 
missing the earnings of the highest earners. The fraction of earners whose earnings are capped in the SER has varied historically, reaching a high point of 36.1 percent of covered workers — and nearly half (49.0 percent) of men with covered earnings — in 1965 (Social Security Administration 2008, Table 4.B4). In 2005, about 6.1 percent of covered workers had earnings over the cap. The DER, in contrast, is a more comprehensive earnings measure, including earnings not covered by OASDI and earnings above the taxable maximum. However, DER data are only available from the early 1980s.

Administrative earnings data are generally more accurate than survey data (because of the advantage of systematic record-keeping mechanisms over simple recall and the legal consequences of misreporting). They—particularly the SER-also allow nearly exact computations of the present value of Social Security at a point in time and of the effect of small variations in earnings histories on the value of Social Security. For example, one can measure whether the 36th year of earnings replaces an earlier year in the PIA computations, and assess its contribution to the value of Social Security.

However, administrative earnings data are not a panacea. These records include errors that arise for a variety of reasons (for example, an employer misunderstands the wage reporting form or a clerk improperly keys in data from a handwritten form), and fields that the administrative agency does not use for paying benefits or collecting taxes may not be maintained as reliably as those that are. Probably more importantly, when earnings records are matched to survey data, not all individuals in the sample are matched to a record (typically because they failed to give permission to match their records or they did not provide adequate information, like a valid Social Security number, to permit a match).

Appendix Table 1 presents information on the match rates to the administrative records for the various surveys we use. Match rates for the SIPP data are generally in the range of 60 to 80 percent overall and are close to 90 percent for the key cohorts we examine (except in the 2001 SIPP, where an anomalously low 65 percent match rate leads us to exclude this panel). HRS match rates are lower, hovering closer to 71 percent

Security taxes. This excluded fraction has shrunk over time (in large part because of changing regulations about who is covered by OASDI), from about 17.5 percent of the civilian labor force in 1955 to about 4.0 percent early this decade (Committee on Ways and Means 2004). 
for the cohorts of greatest interest to us. The fractions of individuals who match is not the sole concern —also important is the representativeness of these cases. Validation studies on both HRS and SIPP matches to administrative records suggest that the match rates vary in important ways based on respondent characteristics (for example, Haider and Solon 2000, Kapteyn et al. 2006, Czajka et al. 2007). In HRS, for example, those who report that they are not working are less likely to offer their Social Security numbers than those with work experience, non-whites are less likely to offer the matching information than whites, and matches are associated with other measures of status, like reported wealth.

In addition to the earnings matches, both surveys include rich information on a variety of other items important for our analyses. SIPP and HRS each include detailed marriage history information, important because of Social Security regulations surrounding marriage duration (e.g., the rule that a marriage that ends in divorce must have lasted at least 10 years in order for an ex-spouse to qualify for spouse or survivor benefits), and for including spousal earnings in calculations of family earnings volatility. In the SIPP, these questions are asked in a topical module that occurs in the second wave of the panel. There are thus selection issues associated with the presence of a marital history (i.e., those who reported a marriage history are non-attriters, and we know that attrition is often correlated with life events—a change in family, schooling, or work status - that are themselves related to earnings volatility). More importantly, we require that married individuals be matched to earnings data on the spouse, and the match rate for spousal records is about 70 to 80 percent for our cohorts (reflecting that not all spouses are in the birth cohorts we examine). Thus the match rate for married survey participants drops to about 90 percent times 80 percent, or close to 70 percent, in the SIPP.

While assets are notoriously difficult to measure, both SIPP and HRS include detailed wealth modules with information on a large number of asset classes. ${ }^{4}$ In the HRS, developers implement bracketing techniques to try to improve the quality of the

\footnotetext{
${ }^{4}$ In HRS, these classes include checking and savings accounts, Certificates of Deposit (CDs), stocks, bonds, mutual funds, Individual Retirement Accounts (IRAs), and Keogh accounts, money markets, homes, other properties, and business assets less debt, including mortgages. We specifically use the wealth estimates constructed by RAND (St. Clair et. al 2008). In SIPP, we use the household aggregates constructed by the Census, including all singly and jointly held assets, less debt, including mortgages.
} 
data and reduce non-response (Juster et al. 1999). SIPP uses extensive imputation for individuals providing inadequate information, but evidence suggests that these procedures were problematic in the 1996 panel, and to a less extent in later panels. The problems are greatest for those trying to compute relationships among asset types or changes in assets, where systematic bias may arise. The asset data problems merely introduce noise into the dependent variable in our use of the data. In general, SIPP asset data appear to be limited-especially in terms of capturing the highest percentiles of the distribution. High wealth individuals are underrepresented, and certain categories of wealth such as own business may be undervalued on average. (Smith, Michelmore, and Toder 2008 compare SIPP and HRS wealth estimates with estimates from the Survey of Consumer Finances, the one survey that is geared particularly to the higher wealth holders whose assets comprise the bulk of U.S. wealth.)

The two data sources' sample frames cover different populations, and offer the potential to estimate impacts for numerous birth cohorts. Using the two data sources also allows validity checks, which may be important in estimating individual-level variances, since modeling the second moment is generally more sensitive to data errors and imputation than modeling the conditional mean. We can compare estimates of the same quantities across the data, and the reliability of the methodology may be assessed, to the extent that the sample frames overlap.

We focus on outcomes for the 1943-1949 birth cohorts. Our choice to focus on these cohorts is motivated in part by data limitations. Detailed earnings information on all earnings (including those in uncovered employment and above the taxable maximum) is only available starting in about 1981 . We seek to use 10 years of data from these earnings histories, and we would like the earnings data to come from prime age workers in the main, so our cohort of workers should over 40 in 1990 and under 62 in 2004. This limits us to individuals born in 1943 (aged 47 in 1990 and 61 in 2004) to 1949 (aged 41 in 1990 and 55 in 2004). We also compare to adjacent 7-year birth-year cohorts, those born 1936-1942 and those born 1950-1956. 


\section{Measures}

We use three separate dependent variables: net worth (total financial assets less liabilities), housing equity (one component of net worth), and Social Security wealth. ${ }^{5}$ Our asset measures include net worth and net housing equity. To illustrate the bounds that result from different assumptions about how wealth is shared within households, we use both a household measure and a per capita measure of net worth. In other regressions not reported here, we also use the cube root of these wealth measures, which produces roughly normal distributions of the dependent variable, eliminating the skewness in wealth. Our qualitative results are unchanged, though the estimated coefficients are more difficult to interpret in those regressions.

Our measure of volatility, VOL, is the year-to-year variability in total earnings reported on Detailed Earnings Records data for the prior five years, i.e. the variance of earnings over five years. It thus reflects short-term, rather than lifetime, volatility. A measure of average volatility is the current volatility ( 1 year to 5 years ago) plus lagged volatility (variance of earnings 6 years to 10 years ago) divided by two. A measure of individual trend, or difference, in volatility is the current volatility (1 year to 5 years ago) less lagged volatility (variance of earnings 6 years to 10 years ago) divided by two. The average volatility measure, AVOL, and the difference, DVOL, sum to the variable VOL, so if the coefficients on AVOL and DVOL are the same, the interpretation of the coefficient on VOL is straightforward. If not, the average level of and change in volatility may have different impacts on wealth.

Our measure of Social Security wealth takes into account both worker and auxiliary benefits and integrates cohort-sex-specific survival probabilities (for both the individual and his/her spouse where applicable) from the Trustees Report (Board of Trustees 2008). ${ }^{6}$ We assume that both workers and their spouses claim benefits at the early eligibility age of 62 and use a discount rate of 2 percent when accumulating

\footnotetext{
${ }^{5}$ An important limitation of our wealth measure is that we do not include wealth from employer-provided pensions. The Health and Retirement Study data include self-reports on defined contribution pensions and can be linked to detailed pension plan characteristics for those respondents who granted permission that enable researchers to compute both defined benefit and defined contribution pension wealth. The SIPP data include more limited pension information, with no capacity to reflect defined benefit pension wealth.
} 
benefits. A particular complication in computing this measure is that in married couple households, both an individual and his or her spouse need to have been matched to the earnings record in order for us to compute this quantity without imputation.

We include Disability Insurance (DI) beneficiaries in the estimation sample, and compute these individuals' Social Security wealth using disability rules, rather than retirement rules. The choice of whether and how to include these individuals in our analyses is a challenging one. On one hand, policy concern about "increased volatility" typically reflects concern in the fraction of overall risk that workers bear independent of disability risk, which a wide variety of social insurance programs address (DI, Supplemental Security Income, Workers' Compensation, and so forth). On the other hand, it is clear that disability application rates vary with economic cycles, though often with a lag (see, for example, Stapleton et al. 1998), so it is difficult to disentangle disability and volatility neatly. In future work, we plan to test the sensitivity of our results to this choice to include individuals with disability spells in the sample.

Our explanatory variables include controls for age and education and measures of earnings volatility. We regress wealth on volatility (last 5 years) and then regress wealth on half the change in volatility (last 5 years minus previous 5 years) and half the sum (average 5-year volatility over two periods or ten years). These two predictors sum to the single predictor in the first regression, and have the interpretation of long-run volatility (average volatility or AVOL) and changes/trends in volatility (DVOL). This is similar to the decomposition used by, for example, Baker et al. (1999).

For our main cohort of interest (born 1943-1949), mortality differentials are likely to play a small role (more important for men than for women), but systematic variation in wealth and earnings volatility over the life cycle may play a role, so we estimate regressions separately by data source (in each of the SIPP panels, and in the HRS).

\section{Results: Rise in Volatility}

We measure volatility at a point in time as the intertemporal variance of earnings using administrative earnings reports from the prior five years. Own earnings offer an

\footnotetext{
${ }^{6}$ When computing Social Security benefits under this strategy, we forward fill an individual's earnings trajectory with zeros. This is consistent with Social Security law. Further, we do not implement the
} 
incomplete measure of economic income, and thus a distorted picture of volatility, but own and spouse earnings constitute most of family income and therefore the variance of summed own and spouse earnings represent the volatility in family income we wish to measure better (see also Nichols and Zimmerman 2008 on own earnings versus family income).

Figure 1a demonstrates that mean family earnings volatility has increased over the period 1990 to 2004, but the trend in mean own earnings volatility is less clear. Though each panel's subsample represents roughly the same population, ${ }^{7}$ those born 1936-1954, the own earnings volatility estimates are surprisingly noisy relative to family earnings volatility. The upward trend in volatility is driven by increasing levels above the median. Trends in the $75^{\text {th }}$ percentile of family earnings volatility look very much like trends in the mean (Figure 1b), whereas trends in the median exhibit no secular trend, but do exhibit cyclical patterns. Trends in mean own earnings volatility are driven by large variation at higher percentiles of the distribution.

\footnotetext{
Retirement Earnings Test (RET).

${ }^{7}$ These repeated national surveys would represent the same population except for two factors: changes due to immigration and mortality, and changes due to changing family structure (some who are never married in 1993 will be married in 1996, and some who are married in 1993 will no longer be matched to spouses, or matched to different spouses in 1996). The projections of future earnings volatility for families in years after the survey assume that family structure remains constant (estimates of past earnings volatility before the start of the survey takes account of the beginning dates of marriage, but cannot account for the contribution of previous spouses). Only in Figures 1 and 2 do these projections of future earnings volatility play a role; elsewhere in the paper only earnings volatility over the ten years preceding the survey is measured.
} 
Figure 1a. Mean family and own earnings volatility by year, by SIPP Panel
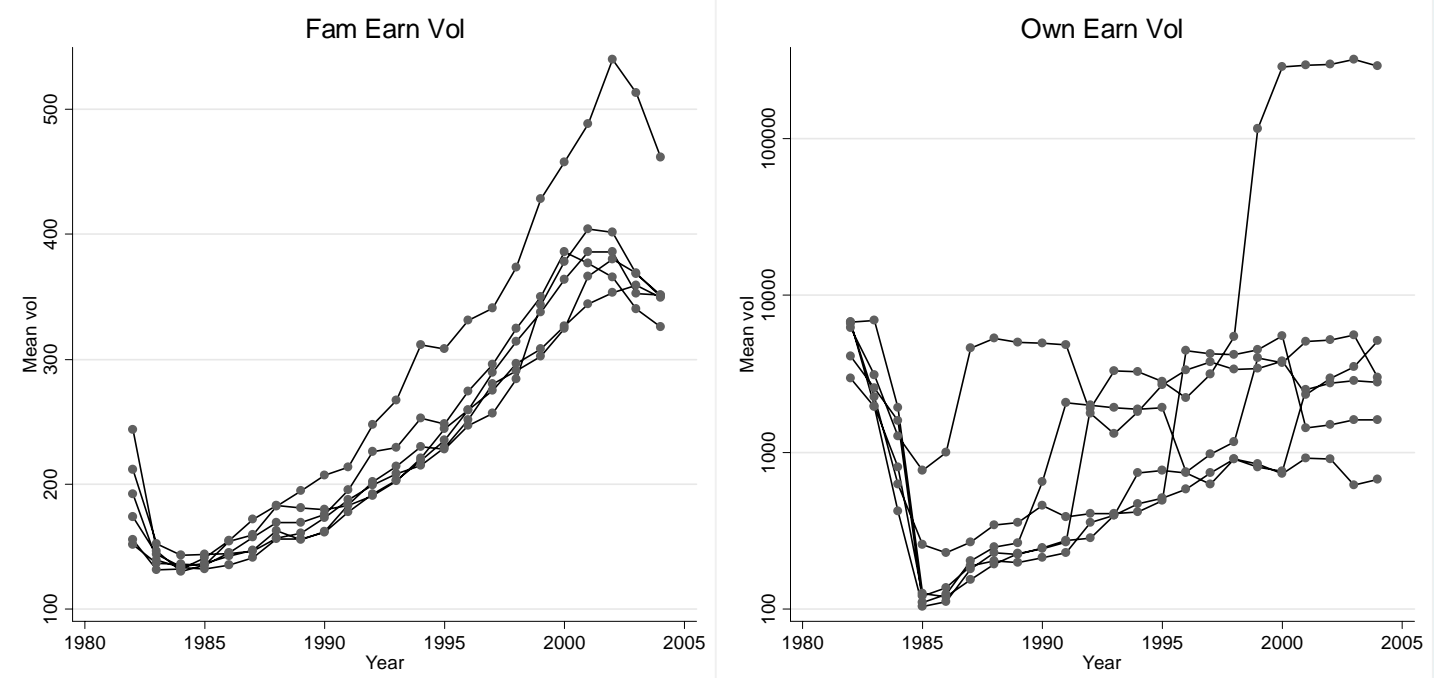

Figure $1 \mathrm{~b} .75^{\text {th }}$ Percentile of family and own earnings volatility by year, by SIPP Panel
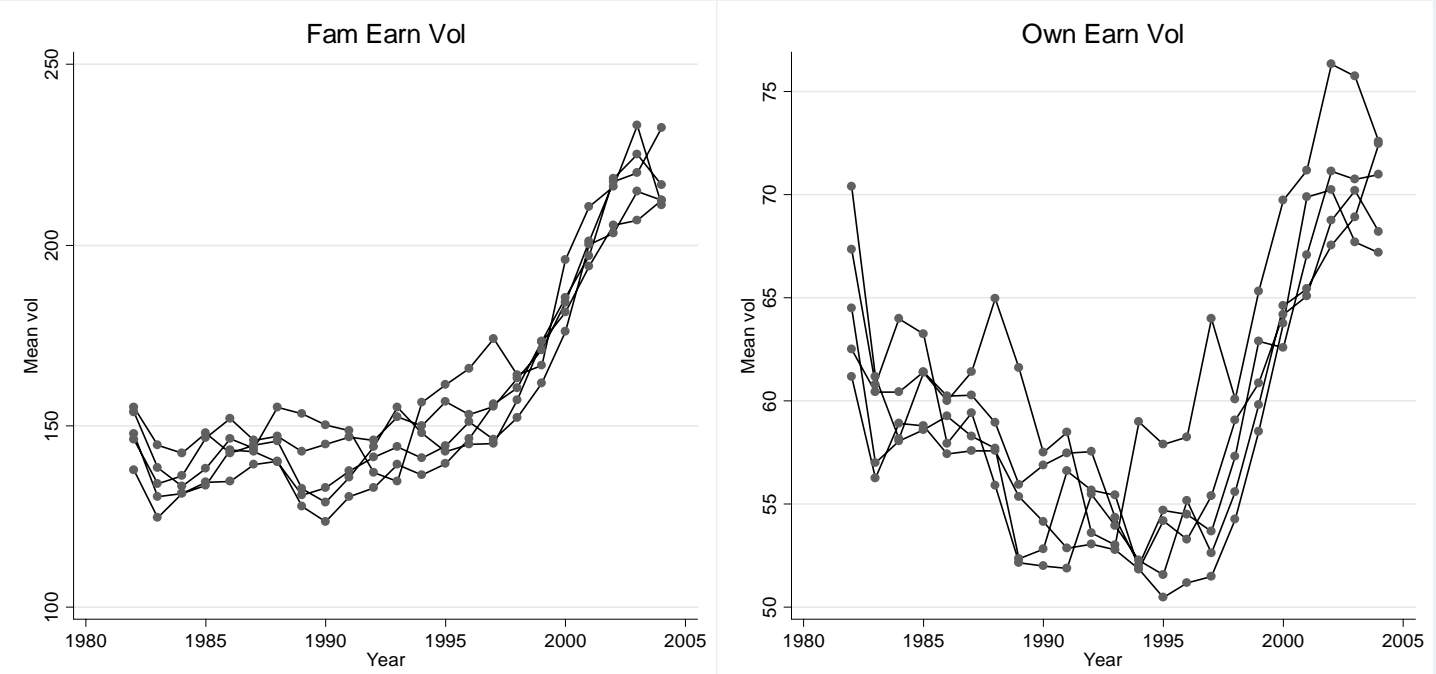

Note: only birth cohorts 1936-1956 are included in calculations; volatility is measured in millions of year-2000 dollars; top one percent of volatility cases in each year are dropped before calculating means; weights are normalized to average one within each panel.

Since the population of those born in 1936-1954 is aging over these years, it is natural to wonder whether the apparent increase in volatility is due to older workers having more volatile incomes. Figure 2 shows that the aging of these cohorts plays a small role, but likely does not drive the observed upward trend. The 2004 survey does produce markedly different estimates from the 1996 survey, however, so it is not clear 
what role changes in surveys or changes in the underlying population may play in explaining the upward trend in volatility in these cohorts. In the rest of our analysis, we exploit cross-sectional variation in volatility, so any failure of identification of trends does not affect our results.

\section{Figure 2. Mean family earnings volatility by year and age, by SIPP Panel}
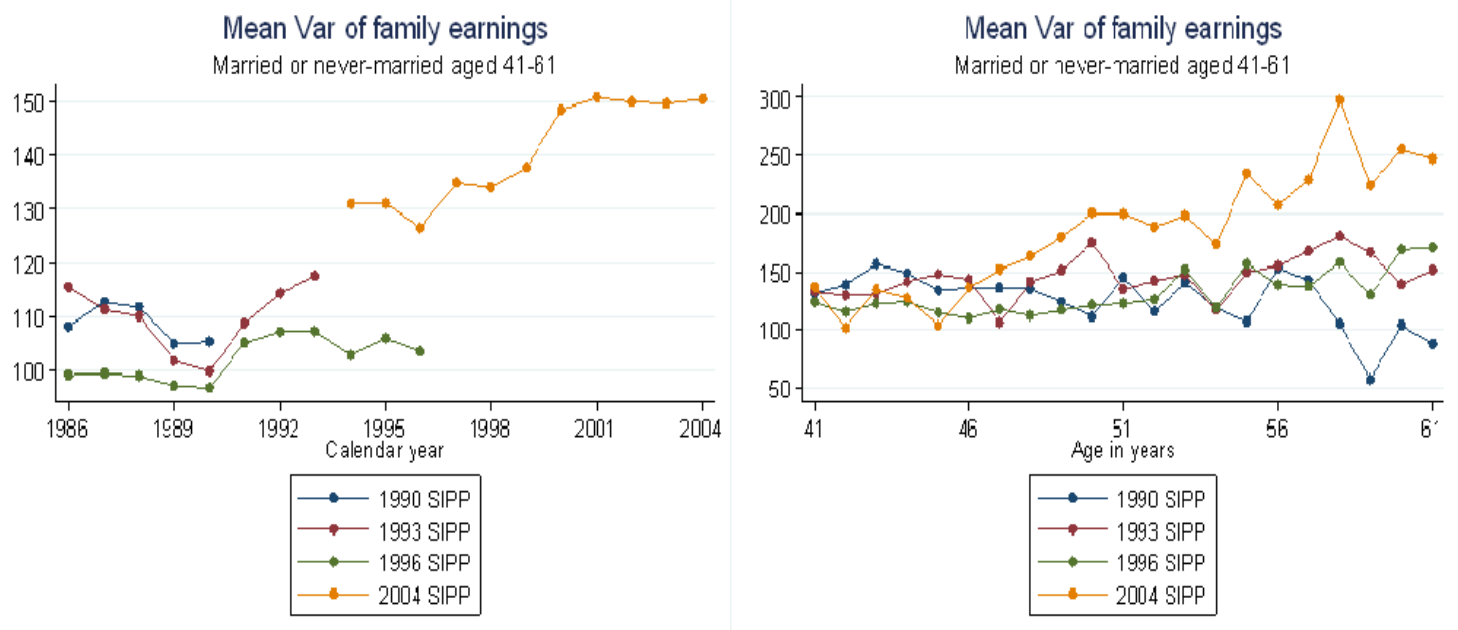

\section{Results: Wealth Distributions}

The distribution of household net worth has shifted to the right over time and become more dispersed for all cohorts we examine, and each cohort experiences a shift in location and spread as it ages. That is, both the mean and variance of wealth increase with age and increase with time for a given age group. However, the distributions are broadly similar, as shown in the following graphs (Figures 3a through 3c), and we estimate separate regressions within panel to ascertain whether the pattern of the association between wealth and earnings volatility has changed over time as our target population ages. 
Figure 3a. Distribution of household net worth by panel, 1936-1956 birth cohorts (censored above \$3million)

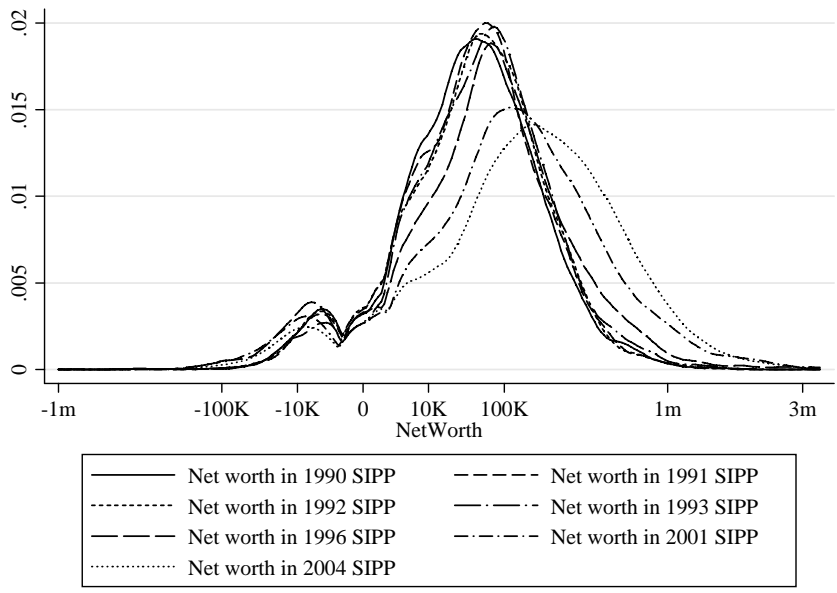

Figure 3b. Distribution of household net worth by birth cohorts, 1990 SIPP (censored above \$3million)

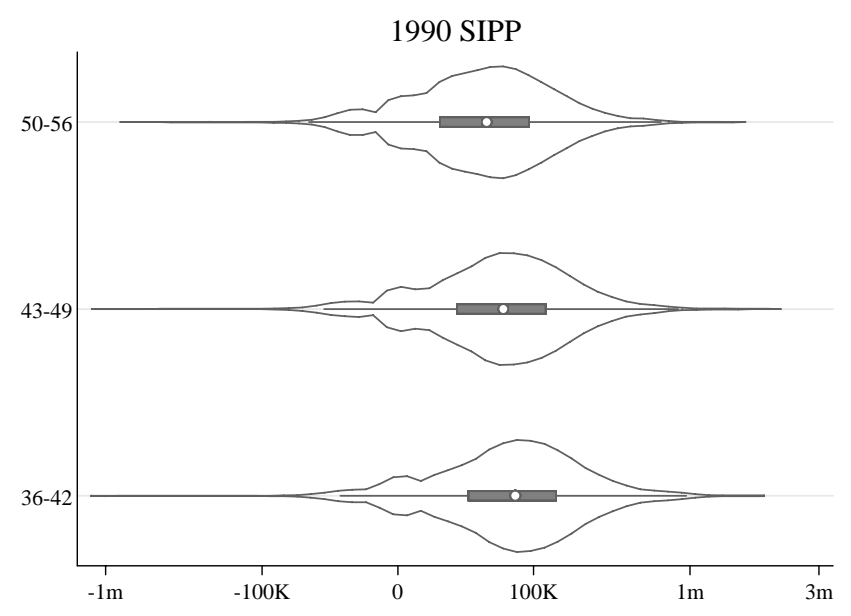


Figure 3c. Distribution of household net worth by birth cohorts, 2004 SIPP (censored above \$3million)

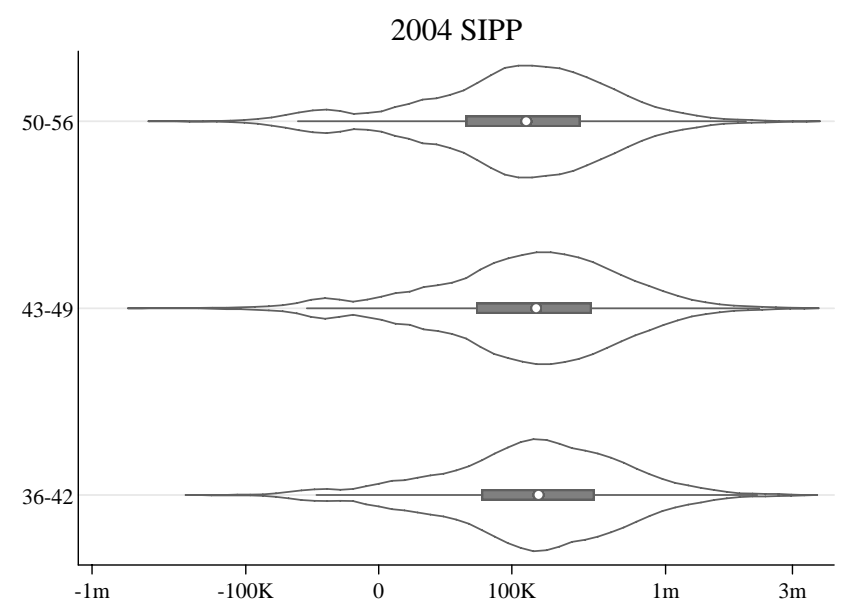

The distribution of per person household net worth has also shifted to the right and increased in variance over time, both within and across cohorts, but exhibits much lower dispersion than household net worth (Figures 4a through 4c).

Figure 4a. Distribution of per-capita household net worth by SIPP panel, 1936-1956 birth cohorts

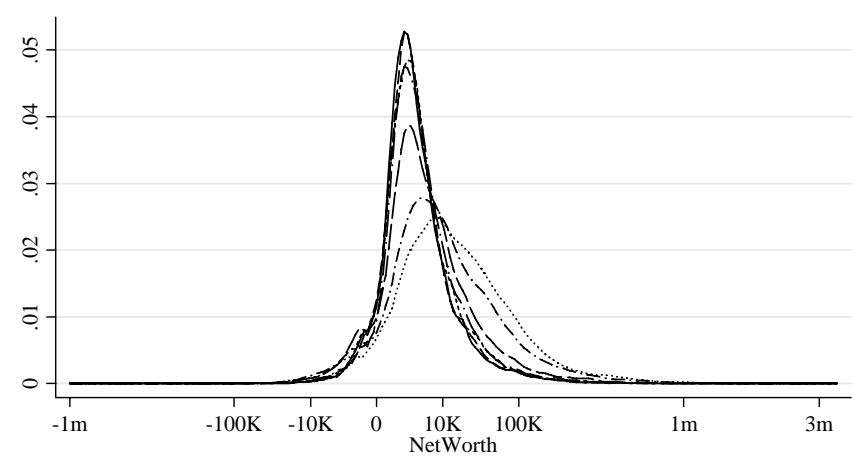

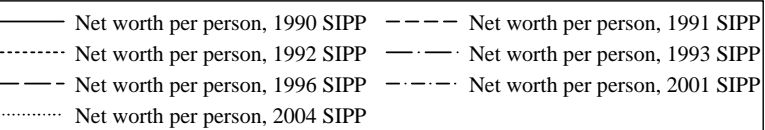


Figure 4b. Distribution of per-capita household net worth by birth cohorts, 1990 SIPP

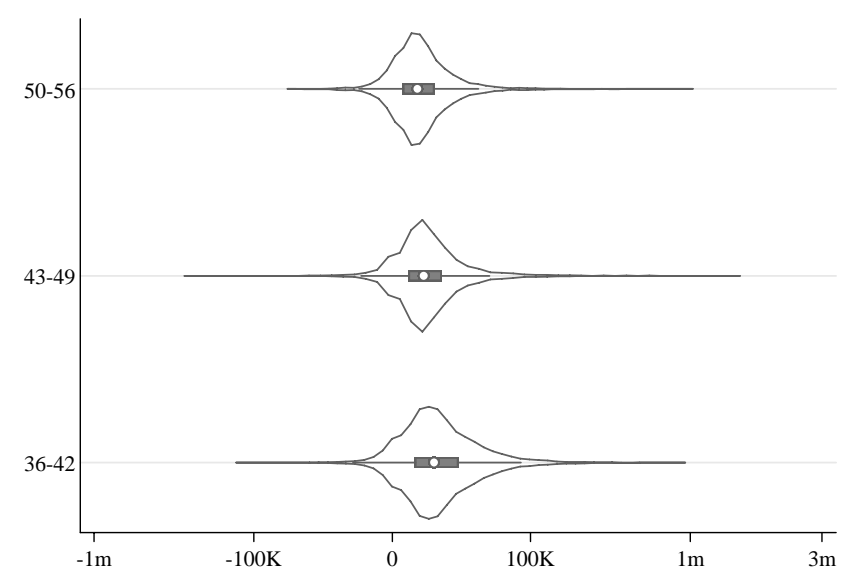

Figure 4c. Distribution of per-capita household net worth by birth cohorts, 2004 SIPP

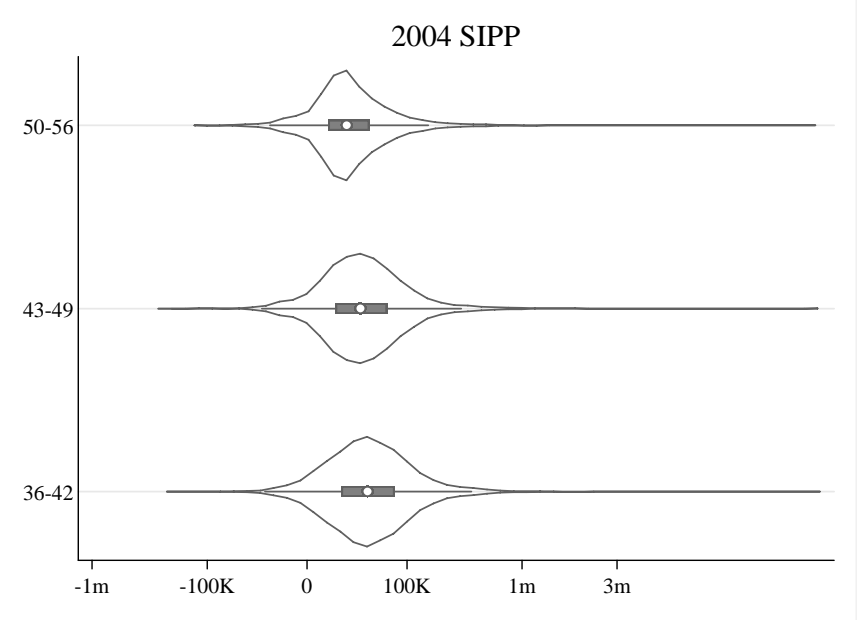

\section{Results: Regressions of wealth on earnings volatility measures}

The regressions of household net worth (Table 1), household net worth per person (Table 2), housing equity (Table 3), Social Security wealth (Table 4), and the sum of household net worth per person and Social Security wealth (Table 5) are presented in the tables below (focusing on the combined SIPP estimates) and in Appendix B (the estimates from the HRS). We juxtapose results for men and women combined (version A 
of each table) with those for men alone (version B). Estimates reproducing the regressions below in each SIPP panel are not qualitatively different from the pooled survey results.

The coefficient estimates suggest that higher volatility is associated with higher wealth in most categories for married people. An increase of 1 unit in earnings volatility (measured in millions of squared dollars) is associated with a \$30 higher net worth among married individuals (Table 1A, column 3) or \$29 among married men (Table 1B, column 3). Such an increase in volatility corresponds to a thought experiment where an individual's earnings are constant in real terms over five years, but one year he or she has a one-time shock of $\$ 2000$. We can think of this as a rough estimate of the marginal propensity to save (on net, ignoring consumption that one could finance through borrowing) being in the one and one half percent range.

Decomposing the apparent effect of volatility into effects due to short-run and long-run volatility components, or the effects of average volatility and changes in volatility, suggests that the association is driven entirely by long-run average volatility. This may be due to heterogeneity in the population, with less risk-averse types more willing to accept volatile earnings streams and earning higher average returns, or it may be due to precautionary savings on the part of those who expect higher future volatility.

Results for never married people sometimes show a reverse pattern, where higher volatility is associated with lower wealth, but results for this subgroup are imprecisely estimated and not statistically significant. 
Table 1. Dependent Variable Total Net Worth, All SIPP Panels A. All

\begin{tabular}{|c|c|c|c|c|}
\hline & $\begin{array}{c}(1) \\
\text { NM1 }\end{array}$ & $\begin{array}{c}(2) \\
\text { NM2 }\end{array}$ & $\begin{array}{c}(3) \\
\text { Mar1 }\end{array}$ & $\begin{array}{c}(4) \\
\text { Mar2 }\end{array}$ \\
\hline Age & $\begin{array}{c}-36110.3 \\
(-1.03)\end{array}$ & $\begin{array}{c}-37261.8 \\
(-1.06)\end{array}$ & $\begin{array}{c}-9080.0 \\
(-0.58)\end{array}$ & $\begin{array}{c}-5739.8 \\
(-0.34)\end{array}$ \\
\hline Age sq. & $\begin{array}{l}468.7 \\
(1.15)\end{array}$ & $\begin{array}{l}478.3 \\
(1.18)\end{array}$ & $\begin{array}{l}201.1 \\
(1.21)\end{array}$ & $\begin{array}{l}165.7 \\
(0.94)\end{array}$ \\
\hline Educ $<12$ th grade & $\begin{array}{c}-60549.0^{* * * *} \\
(-4.83)\end{array}$ & $\begin{array}{c}-59471.3^{* * *} \\
(-4.96)\end{array}$ & $\begin{array}{c}-108270.1^{* * * *} \\
(-4.09)\end{array}$ & $\begin{array}{c}-106654.7^{* * *} \\
(-3.56)\end{array}$ \\
\hline Educ $>12$ th grade & $\begin{array}{c}-32346.6^{* *} \\
(-2.87)\end{array}$ & $\begin{array}{c}-30163.1^{* * *} \\
(-2.62)\end{array}$ & $\begin{array}{c}-75342.4^{* * *} \\
(-3.40)\end{array}$ & $\begin{array}{c}-72868.6^{* *} \\
(-2.96)\end{array}$ \\
\hline 1990 Panel & $\begin{array}{c}105023.0 \\
(1.04)\end{array}$ & $\begin{array}{c}101547.8 \\
(1.00)\end{array}$ & $\begin{array}{c}-94329.9 \\
(-1.24)\end{array}$ & $\begin{array}{c}-101641.4 \\
(-1.24)\end{array}$ \\
\hline 1991 Panel & $\begin{array}{c}86449.7 \\
(0.88)\end{array}$ & $\begin{array}{c}86307.5 \\
(0.88)\end{array}$ & $\begin{array}{c}-116448.9 \\
(-1.53)\end{array}$ & $\begin{array}{c}-122222.0 \\
(-1.48)\end{array}$ \\
\hline 1992 Panel & $\begin{array}{c}97479.7 \\
(1.01)\end{array}$ & $\begin{array}{c}94952.5 \\
(0.98)\end{array}$ & $\begin{array}{c}-113045.6 \\
(-1.46)\end{array}$ & $\begin{array}{c}-121114.1 \\
(-1.45)\end{array}$ \\
\hline 1993 Panel & $\begin{array}{c}99265.0 \\
(1.08)\end{array}$ & $\begin{array}{c}97555.8 \\
(1.05)\end{array}$ & $\begin{array}{c}-103619.8 \\
(-1.32)\end{array}$ & $\begin{array}{c}-108247.6 \\
(-1.27)\end{array}$ \\
\hline 1996 Panel & $\begin{array}{c}105979.8 \\
(1.05)\end{array}$ & $\begin{array}{c}105299.2 \\
(1.04)\end{array}$ & $\begin{array}{c}-114255.2 \\
(-1.42)\end{array}$ & $\begin{array}{c}-124512.5 \\
(-1.44)\end{array}$ \\
\hline Female & $\begin{array}{c}-23405.0 \\
(-1.64)\end{array}$ & $\begin{array}{c}-21719.2 \\
(-1.48)\end{array}$ & $\begin{array}{c}-6228.2 \\
(-0.27)\end{array}$ & $\begin{array}{c}-7191.4 \\
(-0.30)\end{array}$ \\
\hline Avg Earnings & $\begin{array}{l}2.014^{* *} \\
(2.92)\end{array}$ & $\begin{array}{l}1.870^{* *} \\
(2.67)\end{array}$ & $\begin{array}{c}1.364^{* * *} \\
(5.11)\end{array}$ & $\begin{array}{c}1.307^{* * *} \\
(4.33)\end{array}$ \\
\hline Earnings Var & $\begin{array}{l}-4.389 \\
(-0.14)\end{array}$ & & $\begin{array}{c}30.48^{* * * *} \\
(4.27)\end{array}$ & \\
\hline Diff Earnings Var & & $\begin{array}{l}-87.57 \\
(-1.61)\end{array}$ & & $\begin{array}{l}-2.823 \\
(-0.22)\end{array}$ \\
\hline Avg Earnings Var & & $\begin{array}{l}54.44 \\
(1.06)\end{array}$ & & $\begin{array}{c}57.88^{* * *} \\
(4.43)\end{array}$ \\
\hline Constant & $\begin{array}{c}671119.2 \\
(0.95)\end{array}$ & $\begin{array}{c}701666.2 \\
(1.00)\end{array}$ & $\begin{array}{c}217140.1 \\
(0.62)\end{array}$ & $\begin{array}{c}145434.7 \\
(0.40)\end{array}$ \\
\hline Observations & 1645 & 1645 & 14585 & 13600 \\
\hline
\end{tabular}


B. Men Only

\begin{tabular}{|c|c|c|c|c|}
\hline & $\begin{array}{c}\text { (1) } \\
\text { MaleNM1 }\end{array}$ & $\begin{array}{c}(2) \\
\text { MaleNM2 }\end{array}$ & $\begin{array}{c}\text { (3) } \\
\text { MaleMar1 }\end{array}$ & $\begin{array}{c}\text { (4) } \\
\text { MaleMar2 }\end{array}$ \\
\hline Age & $\begin{array}{c}-81665.3 \\
(-1.26)\end{array}$ & $\begin{array}{c}-77479.7 \\
(-1.16)\end{array}$ & $\begin{array}{c}23880.2 \\
(1.17)\end{array}$ & $\begin{array}{c}26830.5 \\
(1.16)\end{array}$ \\
\hline Age sq. & $\begin{array}{l}997.4 \\
(1.32)\end{array}$ & $\begin{array}{l}944.8 \\
(1.21)\end{array}$ & $\begin{array}{l}-162.2 \\
(-0.76)\end{array}$ & $\begin{array}{l}-192.5 \\
(-0.82)\end{array}$ \\
\hline Educ $<12$ th grade & $\begin{array}{c}-81204.7^{* * *} \\
(-4.14)\end{array}$ & $\begin{array}{c}-77101.8^{* * *} \\
(-3.94)\end{array}$ & $\begin{array}{c}-129770.3^{*} \\
(-2.50)\end{array}$ & $\begin{array}{c}-130553.7^{*} \\
(-2.23)\end{array}$ \\
\hline Educ $>12$ th grade & $\begin{array}{c}-30377.8 \\
(-1.65)\end{array}$ & $\begin{array}{c}-24540.0 \\
(-1.23)\end{array}$ & $\begin{array}{c}-103279.1^{*} \\
(-2.19)\end{array}$ & $\begin{array}{c}-103769.8^{*} \\
(-1.99)\end{array}$ \\
\hline 1990 Panel & $\begin{array}{c}254876.2 \\
(1.38)\end{array}$ & $\begin{array}{c}233241.6 \\
(1.21)\end{array}$ & $\begin{array}{c}-225960.4 \\
(-1.62)\end{array}$ & $\begin{array}{c}-237821.9 \\
(-1.58)\end{array}$ \\
\hline 1991 Panel & $\begin{array}{c}214232.1 \\
(1.18)\end{array}$ & $\begin{array}{c}201239.1 \\
(1.08)\end{array}$ & $\begin{array}{c}-247408.8 \\
(-1.77)\end{array}$ & $\begin{array}{c}-256938.0 \\
(-1.69)\end{array}$ \\
\hline 1992 Panel & $\begin{array}{c}242386.8 \\
(1.37)\end{array}$ & $\begin{array}{c}223007.5 \\
(1.21)\end{array}$ & $\begin{array}{c}-247589.0 \\
(-1.73)\end{array}$ & $\begin{array}{c}-260814.7 \\
(-1.69)\end{array}$ \\
\hline 1993 Panel & $\begin{array}{c}236866.5 \\
(1.38)\end{array}$ & $\begin{array}{c}217985.2 \\
(1.21)\end{array}$ & $\begin{array}{c}-236609.4 \\
(-1.63)\end{array}$ & $\begin{array}{c}-247765.9 \\
(-1.57)\end{array}$ \\
\hline 1996 Panel & $\begin{array}{c}266218.6 \\
(1.33)\end{array}$ & $\begin{array}{c}251920.8 \\
(1.22)\end{array}$ & $\begin{array}{c}-235948.4 \\
(-1.56)\end{array}$ & $\begin{array}{c}-254690.7 \\
(-1.56)\end{array}$ \\
\hline Avg Earnings & $\begin{array}{l}2.244 \\
(1.81)\end{array}$ & $\begin{array}{l}1.917 \\
(1.49)\end{array}$ & $\begin{array}{l}1.104^{*} \\
(2.23)\end{array}$ & $\begin{array}{l}1.050 \\
(1.82)\end{array}$ \\
\hline Earnings Var & $\begin{array}{l}-37.72 \\
(-0.55)\end{array}$ & & $\begin{array}{c}28.83^{* * * *} \\
(3.68)\end{array}$ & \\
\hline Diff Earnings Var & & $\begin{array}{l}-191.3^{*} \\
(-2.29)\end{array}$ & & $\begin{array}{l}12.02 \\
(0.85)\end{array}$ \\
\hline Avg Earnings Var & & $\begin{array}{l}79.63 \\
(0.70)\end{array}$ & & $\begin{array}{l}44.95^{* *} \\
(3.16)\end{array}$ \\
\hline Constant & $\begin{array}{c}1479557.6 \\
(1.19)\end{array}$ & $\begin{array}{c}1412316.9 \\
(1.11)\end{array}$ & $\begin{array}{c}-386620.8 \\
(-0.88)\end{array}$ & $\begin{array}{c}-444410.6 \\
(-0.95)\end{array}$ \\
\hline Observations & 763 & 763 & 7294 & 6792 \\
\hline
\end{tabular}

Notes: NM=never-married, Mar=married

$t$ statistics in parentheses; ${ }^{*} p<0.05,{ }^{* *} p<0.01,{ }^{* * *} p<0.001$ 
Table 2. Dependent Variable Per capita Household Net Worth, All SIPP Panels A. All

\begin{tabular}{|c|c|c|c|c|}
\hline & $\begin{array}{c}(1) \\
\text { NM1 }\end{array}$ & $\begin{array}{c}(2) \\
\text { NM2 }\end{array}$ & $\begin{array}{c}\text { (3) } \\
\text { Mar1 }\end{array}$ & $\begin{array}{c}(4) \\
\text { Mar2 }\end{array}$ \\
\hline Age & $\begin{array}{c}-31626.8 \\
(-1.00)\end{array}$ & $\begin{array}{c}-32402.2 \\
(-1.03)\end{array}$ & $\begin{array}{c}-9571.8 \\
(-1.33)\end{array}$ & $\begin{array}{c}-8884.4 \\
(-1.16)\end{array}$ \\
\hline Age sq. & $\begin{array}{l}413.5 \\
(1.10)\end{array}$ & $\begin{array}{l}420.0 \\
(1.12)\end{array}$ & $\begin{array}{l}159.0^{*} \\
(2.07)\end{array}$ & $\begin{array}{l}151.6 \\
(1.86)\end{array}$ \\
\hline Educ $<12$ th grade & $\begin{array}{c}-42514.3^{* * * *} \\
(-5.34)\end{array}$ & $\begin{array}{c}-41788.7^{* * *} \\
(-5.57)\end{array}$ & $\begin{array}{c}-41528.6^{* *} \\
(-3.17)\end{array}$ & $\begin{array}{c}-40711.8^{* *} \\
(-2.76)\end{array}$ \\
\hline Educ $>12$ th grade & $\begin{array}{c}-31830.6^{* * * *} \\
(-3.80)\end{array}$ & $\begin{array}{c}-30360.3^{* * *} \\
(-3.51)\end{array}$ & $\begin{array}{c}-26992.7^{*} \\
(-2.45)\end{array}$ & $\begin{array}{c}-25656.0^{*} \\
(-2.11)\end{array}$ \\
\hline 1990 Panel & $\begin{array}{c}93854.7 \\
(0.96)\end{array}$ & $\begin{array}{c}91514.6 \\
(0.93)\end{array}$ & $\begin{array}{c}-48349.0 \\
(-1.29)\end{array}$ & $\begin{array}{c}-51493.0 \\
(-1.27)\end{array}$ \\
\hline 1991 Panel & $\begin{array}{c}89432.2 \\
(0.93)\end{array}$ & $\begin{array}{c}89336.5 \\
(0.93)\end{array}$ & $\begin{array}{c}-55365.9 \\
(-1.47)\end{array}$ & $\begin{array}{c}-57677.5 \\
(-1.41)\end{array}$ \\
\hline 1992 Panel & $\begin{array}{c}92622.4 \\
(0.99)\end{array}$ & $\begin{array}{c}90920.7 \\
(0.96)\end{array}$ & $\begin{array}{c}-53543.8 \\
(-1.40)\end{array}$ & $\begin{array}{c}-56932.5 \\
(-1.38)\end{array}$ \\
\hline 1993 Panel & $\begin{array}{c}94810.5 \\
(1.05)\end{array}$ & $\begin{array}{c}93659.6 \\
(1.04)\end{array}$ & $\begin{array}{c}-52037.7 \\
(-1.34)\end{array}$ & $\begin{array}{c}-54365.4 \\
(-1.29)\end{array}$ \\
\hline 1996 Panel & $\begin{array}{c}99371.7 \\
(1.00)\end{array}$ & $\begin{array}{c}98913.4 \\
(0.99)\end{array}$ & $\begin{array}{c}-54847.6 \\
(-1.38)\end{array}$ & $\begin{array}{c}-59508.7 \\
(-1.38)\end{array}$ \\
\hline Female & $\begin{array}{c}-20465.9 \\
(-1.57)\end{array}$ & $\begin{array}{c}-19330.7 \\
(-1.43)\end{array}$ & $\begin{array}{l}-2385.3 \\
(-0.21)\end{array}$ & $\begin{array}{l}-2666.6 \\
(-0.22)\end{array}$ \\
\hline Avg Earnings & $\begin{array}{l}1.865^{* *} \\
(3.06)\end{array}$ & $\begin{array}{l}1.768^{* *} \\
(2.73)\end{array}$ & $\begin{array}{c}0.418^{* * *} \\
(3.51)\end{array}$ & $\begin{array}{l}0.388^{* *} \\
(2.92)\end{array}$ \\
\hline Earnings Var & $\begin{array}{l}-15.23 \\
(-0.54)\end{array}$ & & $\begin{array}{c}13.47^{* * *} \\
(4.02)\end{array}$ & \\
\hline Diff Earnings Var & & $\begin{array}{l}-71.24^{*} \\
(-2.00)\end{array}$ & & $\begin{array}{l}1.670 \\
(0.30)\end{array}$ \\
\hline Avg Earnings Var & & $\begin{array}{l}24.38 \\
(0.51)\end{array}$ & & $\begin{array}{c}23.28^{* * * *} \\
(3.79)\end{array}$ \\
\hline Constant & $\begin{array}{c}548523.5 \\
(0.92)\end{array}$ & $\begin{array}{c}569092.5 \\
(0.96)\end{array}$ & $\begin{array}{c}196002.6 \\
(1.23)\end{array}$ & $\begin{array}{c}182676.7 \\
(1.13)\end{array}$ \\
\hline Observations & 1645 & 1645 & 14585 & 13600 \\
\hline
\end{tabular}


B. Men only

\begin{tabular}{|c|c|c|c|c|}
\hline & $\begin{array}{c}(1) \\
\text { MaleNM1 }\end{array}$ & $\begin{array}{c}(2) \\
\text { MaleNM2 }\end{array}$ & $\begin{array}{c}(3) \\
\text { MaleMar1 }\end{array}$ & $\begin{array}{c}(4) \\
\text { MaleMar2 }\end{array}$ \\
\hline Age & $\begin{array}{c}-63920.2 \\
(-1.07)\end{array}$ & $\begin{array}{c}-61532.1 \\
(-1.00)\end{array}$ & $\begin{array}{l}-604.4 \\
(-0.07)\end{array}$ & $\begin{array}{l}153.2 \\
(0.01)\end{array}$ \\
\hline Age sq. & $\begin{array}{l}815.9 \\
(1.14)\end{array}$ & $\begin{array}{r}785.9 \\
(1.06)\end{array}$ & $\begin{array}{l}58.43 \\
(0.61)\end{array}$ & $\begin{array}{l}50.80 \\
(0.47)\end{array}$ \\
\hline Educ $<12$ th grade & $\begin{array}{c}-61557.7^{* * *} \\
(-4.08)\end{array}$ & $\begin{array}{c}-59216.8^{* * *} \\
(-3.84)\end{array}$ & $\begin{array}{c}-51749.9^{*} \\
(-1.99)\end{array}$ & $\begin{array}{c}-51956.5 \\
(-1.78)\end{array}$ \\
\hline Educ $>12$ th grade & $\begin{array}{c}-35992.4^{*} \\
(-2.48)\end{array}$ & $\begin{array}{c}-32661.7^{*} \\
(-2.03)\end{array}$ & $\begin{array}{c}-39847.3 \\
(-1.69)\end{array}$ & $\begin{array}{c}-39866.8 \\
(-1.53)\end{array}$ \\
\hline 1990 Panel & $\begin{array}{c}238691.2 \\
(1.32)\end{array}$ & $\begin{array}{c}226347.6 \\
(1.20)\end{array}$ & $\begin{array}{c}-103553.1 \\
(-1.51)\end{array}$ & $\begin{array}{c}-109141.5 \\
(-1.46)\end{array}$ \\
\hline 1991 Panel & $\begin{array}{c}215764.1 \\
(1.21)\end{array}$ & $\begin{array}{c}208351.0 \\
(1.13)\end{array}$ & $\begin{array}{c}-110288.3 \\
(-1.60)\end{array}$ & $\begin{array}{c}-115070.8 \\
(-1.52)\end{array}$ \\
\hline 1992 Panel & $\begin{array}{c}227629.3 \\
(1.31)\end{array}$ & $\begin{array}{c}216572.6 \\
(1.20)\end{array}$ & $\begin{array}{c}-109686.8 \\
(-1.55)\end{array}$ & $\begin{array}{c}-116012.1 \\
(-1.50)\end{array}$ \\
\hline 1993 Panel & $\begin{array}{c}229030.0 \\
(1.35)\end{array}$ & $\begin{array}{c}218257.4 \\
(1.24)\end{array}$ & $\begin{array}{c}-107577.9 \\
(-1.50)\end{array}$ & $\begin{array}{c}-113347.4 \\
(-1.44)\end{array}$ \\
\hline 1996 Panel & $\begin{array}{c}251272.2 \\
(1.26)\end{array}$ & $\begin{array}{c}243114.7 \\
(1.19)\end{array}$ & $\begin{array}{c}-106895.8 \\
(-1.42)\end{array}$ & $\begin{array}{c}-116440.9 \\
(-1.42)\end{array}$ \\
\hline Avg Earnings & $\begin{array}{l}2.173 \\
(1.91)\end{array}$ & $\begin{array}{l}1.986 \\
(1.58)\end{array}$ & $\begin{array}{l}0.296 \\
(1.22)\end{array}$ & $\begin{array}{l}0.260 \\
(0.93)\end{array}$ \\
\hline Earnings Var & $\begin{array}{l}-46.09 \\
(-0.71)\end{array}$ & & $\begin{array}{c}12.59^{* * * *} \\
(3.37)\end{array}$ & \\
\hline Diff Earnings Var & & $\begin{array}{c}-133.7^{*} \\
(-2.43)\end{array}$ & & $\begin{array}{l}8.703 \\
(1.45)\end{array}$ \\
\hline Avg Earnings Var & & $\begin{array}{l}20.87 \\
(0.18)\end{array}$ & & $\begin{array}{l}17.28^{*} \\
(2.56)\end{array}$ \\
\hline Constant & $\begin{array}{c}1021904.4 \\
(0.93)\end{array}$ & $\begin{array}{c}983540.4 \\
(0.87)\end{array}$ & $\begin{array}{c}57080.1 \\
(0.30) \\
\end{array}$ & $\begin{array}{c}45245.9 \\
(0.22)\end{array}$ \\
\hline Observations & 763 & 763 & 7294 & 6792 \\
\hline
\end{tabular}


Table 3. Dependent Variable Home Equity, All SIPP Panels A. All

\begin{tabular}{|c|c|c|c|c|}
\hline & $\begin{array}{c}(1) \\
\text { NM1 }\end{array}$ & $\begin{array}{c}(2) \\
\text { NM2 }\end{array}$ & $\begin{array}{l}\text { (3) } \\
\text { Mar1 }\end{array}$ & $\begin{array}{c}(4) \\
\text { Mar2 }\end{array}$ \\
\hline Age & $\begin{array}{l}848.9 \\
(0.07)\end{array}$ & $\begin{array}{l}463.5 \\
(0.04)\end{array}$ & $\begin{array}{c}-3341.4 \\
(-0.63)\end{array}$ & $\begin{array}{c}-1744.1 \\
(-0.32)\end{array}$ \\
\hline Age sq. & $\begin{array}{l}-1.704 \\
(-0.01)\end{array}$ & $\begin{array}{l}1.535 \\
(0.01)\end{array}$ & $\begin{array}{l}60.95 \\
(1.08)\end{array}$ & $\begin{array}{l}44.23 \\
(0.77)\end{array}$ \\
\hline Educ $<12$ th grade & $\begin{array}{c}-23880.2^{* * *} \\
(-4.70)\end{array}$ & $\begin{array}{c}-23519.6^{* * *} \\
(-4.67)\end{array}$ & $\begin{array}{c}-26292.0^{* * *} \\
(-9.97)\end{array}$ & $\begin{array}{c}-25999.3^{* * *} \\
(-9.32)\end{array}$ \\
\hline Educ $>12$ th grade & $\begin{array}{c}-9817.3^{*} \\
(-2.10)\end{array}$ & $\begin{array}{c}-9086.6 \\
(-1.94)\end{array}$ & $\begin{array}{c}-15261.6^{* * *} \\
(-8.31)\end{array}$ & $\begin{array}{c}-14996.8^{* * *} \\
(-7.74)\end{array}$ \\
\hline 1990 Panel & $\begin{array}{c}-24178.9 \\
(-1.41)\end{array}$ & $\begin{array}{c}-25341.8 \\
(-1.52)\end{array}$ & $\begin{array}{c}-16380.4 \\
(-1.79)\end{array}$ & $\begin{array}{c}-18132.8 \\
(-1.96)\end{array}$ \\
\hline 1991 Panel & $\begin{array}{c}-18434.0 \\
(-1.06)\end{array}$ & $\begin{array}{c}-18481.6 \\
(-1.09)\end{array}$ & $\begin{array}{c}-16903.2 \\
(-1.86)\end{array}$ & $\begin{array}{c}-17744.5 \\
(-1.92)\end{array}$ \\
\hline 1992 Panel & $\begin{array}{c}-19835.9 \\
(-1.19)\end{array}$ & $\begin{array}{c}-20681.6 \\
(-1.28)\end{array}$ & $\begin{array}{c}-18050.1^{*} \\
(-2.00)\end{array}$ & $\begin{array}{c}-18888.0^{*} \\
(-2.07)\end{array}$ \\
\hline 1993 Panel & $\begin{array}{c}-13730.2 \\
(-0.84)\end{array}$ & $\begin{array}{c}-14302.1 \\
(-0.90)\end{array}$ & $\begin{array}{c}-19018.4^{*} \\
(-2.15)\end{array}$ & $\begin{array}{c}-19627.7^{*} \\
(-2.20)\end{array}$ \\
\hline 1996 Panel & $\begin{array}{c}-3961.2 \\
(-0.28)\end{array}$ & $\begin{array}{c}-4188.9 \\
(-0.31)\end{array}$ & $\begin{array}{c}-23011.2^{* *} \\
(-2.83)\end{array}$ & $\begin{array}{c}-23833.0^{* *} \\
(-2.90)\end{array}$ \\
\hline Female & $\begin{array}{c}-2565.1 \\
(-0.66)\end{array}$ & $\begin{array}{c}-2000.9 \\
(-0.52)\end{array}$ & $\begin{array}{c}5853.7^{* * *} \\
(6.44)\end{array}$ & $\begin{array}{c}5660.8^{* * *} \\
(6.11)\end{array}$ \\
\hline Avg Earnings & $\begin{array}{c}0.443^{* * * *} \\
(4.35)\end{array}$ & $\begin{array}{c}0.395^{* * * *} \\
(3.94)\end{array}$ & $\begin{array}{c}0.458^{* * *} \\
(13.15)\end{array}$ & $\begin{array}{c}0.462^{* * *} \\
(12.50)\end{array}$ \\
\hline Earnings Var & $\begin{array}{l}10.08 \\
(1.15)\end{array}$ & & $\begin{array}{l}4.812^{* *} \\
(2.67)\end{array}$ & \\
\hline Diff Earnings Var & & $\begin{array}{l}-17.76 \\
(-1.20)\end{array}$ & & $\begin{array}{l}-2.890 \\
(-0.77)\end{array}$ \\
\hline Avg Earnings Var & & $\begin{array}{l}29.76^{* *} \\
(2.59)\end{array}$ & & $\begin{array}{c}10.00^{* * * *} \\
(3.56)\end{array}$ \\
\hline Constant & $\begin{array}{c}24672.2 \\
(0.09)\end{array}$ & $\begin{array}{c}34894.2 \\
(0.13)\end{array}$ & $\begin{array}{c}85604.9 \\
(0.71)\end{array}$ & $\begin{array}{c}48748.0 \\
(0.39)\end{array}$ \\
\hline Observations & 1645 & 1645 & 14585 & 13600 \\
\hline
\end{tabular}


B. Men only

\begin{tabular}{|c|c|c|c|c|}
\hline & $\begin{array}{c}1) \\
\text { MaleNM1 } \\
\end{array}$ & $\begin{array}{c}(2) \\
\text { MaleNM2 } \\
\end{array}$ & $\begin{array}{c}3) \\
\text { MaleMar1 } \\
\end{array}$ & $\begin{array}{c}(4) \\
\text { MaleMar2 } \\
\end{array}$ \\
\hline Age & $\begin{array}{c}1668.0 \\
(0.09)\end{array}$ & $\begin{array}{c}2546.3 \\
(0.14)\end{array}$ & $\begin{array}{c}6920.4 \\
(1.00)\end{array}$ & $\begin{array}{c}7082.7 \\
(1.00)\end{array}$ \\
\hline Age sq. & $\begin{array}{l}-10.73 \\
(-0.06)\end{array}$ & $\begin{array}{l}-21.78 \\
(-0.12)\end{array}$ & $\begin{array}{l}-55.38 \\
(-0.76)\end{array}$ & $\begin{array}{l}-57.36 \\
(-0.77)\end{array}$ \\
\hline Educ $<12$ th grade & $\begin{array}{c}-26515.7^{* * *} \\
(-3.43)\end{array}$ & $\begin{array}{c}-25654.7^{* * *} \\
(-3.32)\end{array}$ & $\begin{array}{c}-24681.1^{* * * *} \\
(-7.80)\end{array}$ & $\begin{array}{c}-24138.4^{* * *} \\
(-7.29)\end{array}$ \\
\hline Educ $>12$ th grade & $\begin{array}{c}-3268.1 \\
(-0.44)\end{array}$ & $\begin{array}{c}-2043.1 \\
(-0.27)\end{array}$ & $\begin{array}{c}-14858.9^{* * *} \\
(-6.34)\end{array}$ & $\begin{array}{c}-14652.0^{* * *} \\
(-6.05)\end{array}$ \\
\hline 1990 Panel & $\begin{array}{c}-20677.2 \\
(-0.79)\end{array}$ & $\begin{array}{c}-25216.9 \\
(-0.97)\end{array}$ & $\begin{array}{c}-33808.4^{* *} \\
(-3.01)\end{array}$ & $\begin{array}{c}-35660.3^{* *} \\
(-3.08)\end{array}$ \\
\hline 1991 Panel & $\begin{array}{c}-12753.2 \\
(-0.46)\end{array}$ & $\begin{array}{c}-15479.6 \\
(-0.57)\end{array}$ & $\begin{array}{c}-36842.5^{* *} \\
(-3.28)\end{array}$ & $\begin{array}{c}-36916.8^{* *} \\
(-3.18)\end{array}$ \\
\hline 1992 Panel & $\begin{array}{c}-11843.6 \\
(-0.46)\end{array}$ & $\begin{array}{c}-15910.0 \\
(-0.62)\end{array}$ & $\begin{array}{c}-36736.6^{* * *} \\
(-3.32)\end{array}$ & $\begin{array}{c}-37327.0^{* *} \\
(-3.27)\end{array}$ \\
\hline 1993 Panel & $\begin{array}{c}-10830.9 \\
(-0.42)\end{array}$ & $\begin{array}{c}-14792.8 \\
(-0.58)\end{array}$ & $\begin{array}{c}-37617.8^{* * *} \\
(-3.47)\end{array}$ & $\begin{array}{c}-38047.9^{* * *} \\
(-3.41)\end{array}$ \\
\hline 1996 Panel & $\begin{array}{c}3930.1 \\
(0.17)\end{array}$ & $\begin{array}{l}930.0 \\
(0.04)\end{array}$ & $\begin{array}{c}-38981.1^{* * * *} \\
(-3.96)\end{array}$ & $\begin{array}{c}-39294.0^{* * *} \\
(-3.88)\end{array}$ \\
\hline Avg Earnings & $\begin{array}{l}0.265 \\
(1.77)\end{array}$ & $\begin{array}{l}0.196 \\
(1.37)\end{array}$ & $\begin{array}{c}0.483^{* * *} \\
(11.89)\end{array}$ & $\begin{array}{l}0.500^{* * *} \\
(12.32)\end{array}$ \\
\hline Earnings Var & $\begin{array}{l}15.60 \\
(1.00)\end{array}$ & & $\begin{array}{l}3.937 \\
(1.90)\end{array}$ & \\
\hline Diff Earnings Var & & $\begin{array}{l}-16.62 \\
(-0.72)\end{array}$ & & $\begin{array}{l}-3.098 \\
(-0.67)\end{array}$ \\
\hline Avg Earnings Var & & $\begin{array}{l}40.23^{*} \\
(2.21)\end{array}$ & & $\begin{array}{l}8.362^{*} \\
(2.44)\end{array}$ \\
\hline Constant & $\begin{array}{c}1608.0 \\
(0.00)\end{array}$ & $\begin{array}{c}-12501.4 \\
(-0.03)\end{array}$ & $\begin{array}{c}-116577.2 \\
(-0.75)\end{array}$ & $\begin{array}{c}-119916.4 \\
(-0.75)\end{array}$ \\
\hline Observations & 763 & 763 & 7294 & 6792 \\
\hline
\end{tabular}


Table 4. Dependent variable Social Security wealth, all SIPP panels

A. All

\begin{tabular}{|c|c|c|c|c|}
\hline & $\begin{array}{c}(1) \\
\text { NM1 }\end{array}$ & $\begin{array}{c}(2) \\
\text { NM2 }\end{array}$ & $\begin{array}{c}\text { (3) } \\
\text { Mar1 }\end{array}$ & $\begin{array}{c}(4) \\
\text { Mar2 }\end{array}$ \\
\hline Age & $\begin{array}{c}-14568.6 \\
(-1.65)\end{array}$ & $\begin{array}{c}-14568.0 \\
(-1.65)\end{array}$ & $\begin{array}{c}-8759.1^{* *} \\
(-3.24)\end{array}$ & $\begin{array}{c}-9507.7^{* * *} \\
(-3.42)\end{array}$ \\
\hline Age sq. & $\begin{array}{l}162.7 \\
(1.72)\end{array}$ & $\begin{array}{l}162.7 \\
(1.72)\end{array}$ & $\begin{array}{c}118.0^{* * *} \\
(4.07)\end{array}$ & $\begin{array}{c}125.8^{* * *} \\
(4.23)\end{array}$ \\
\hline Educ $<12$ th grade & $\begin{array}{c}-33295.5^{* * *} \\
(-7.86)\end{array}$ & $\begin{array}{c}-33296.1^{* * *} \\
(-7.88)\end{array}$ & $\begin{array}{c}-12063.5^{* * *} \\
(-7.75)\end{array}$ & $\begin{array}{c}-11434.9^{* * * *} \\
(-7.15)\end{array}$ \\
\hline Educ $>12$ th grade & $\begin{array}{c}-8663.2^{* *} \\
(-2.87)\end{array}$ & $\begin{array}{c}-8664.4^{* *} \\
(-2.89)\end{array}$ & $\begin{array}{c}-2294.6^{* *} \\
(-2.88)\end{array}$ & $\begin{array}{c}-1876.5^{*} \\
(-2.30)\end{array}$ \\
\hline 1990 Panel & $\begin{array}{c}-40746.8^{* *} \\
(-3.01)\end{array}$ & $\begin{array}{c}-40744.9^{* *} \\
(-3.01)\end{array}$ & $\begin{array}{c}-44017.8^{* * *} \\
(-10.37)\end{array}$ & $\begin{array}{c}-43775.4^{* * *} \\
(-10.06)\end{array}$ \\
\hline 1991 Panel & $\begin{array}{c}-31186.1^{*} \\
(-2.26)\end{array}$ & $\begin{array}{c}-31186.0^{*} \\
(-2.26)\end{array}$ & $\begin{array}{c}-40074.9^{* * *} \\
(-9.33)\end{array}$ & $\begin{array}{c}-39671.6^{* * *} \\
(-9.00)\end{array}$ \\
\hline 1992 Panel & $\begin{array}{c}-27636.0^{*} \\
(-2.03)\end{array}$ & $\begin{array}{c}-27634.5^{*} \\
(-2.03)\end{array}$ & $\begin{array}{c}-37331.4^{* * *} \\
(-8.73)\end{array}$ & $\begin{array}{c}-36483.9^{* * *} \\
(-8.32)\end{array}$ \\
\hline 1993 Panel & $\begin{array}{c}-25788.4 \\
(-1.91)\end{array}$ & $\begin{array}{c}-25787.4 \\
(-1.90)\end{array}$ & $\begin{array}{c}-28950.4^{* * *} \\
(-6.83)\end{array}$ & $\begin{array}{c}-28382.7^{* * *} \\
(-6.53)\end{array}$ \\
\hline 1996 Panel & $\begin{array}{c}-16256.2 \\
(-1.33)\end{array}$ & $\begin{array}{c}-16255.7 \\
(-1.33)\end{array}$ & $\begin{array}{c}-22989.9^{* * *} \\
(-5.97)\end{array}$ & $\begin{array}{c}-22564.3^{* * *} \\
(-5.70)\end{array}$ \\
\hline Female & $\begin{array}{c}5444.0^{*} \\
(2.28)\end{array}$ & $\begin{array}{c}5443.0^{*} \\
(2.26)\end{array}$ & $\begin{array}{c}-32908.8^{* * *} \\
(-40.73)\end{array}$ & $\begin{array}{c}-33883.2^{* * *} \\
(-40.77)\end{array}$ \\
\hline Avg Earnings & $\begin{array}{c}0.585^{* * * *} \\
(6.79)\end{array}$ & $\begin{array}{c}0.586^{* * *} \\
(6.45)\end{array}$ & $\begin{array}{l}0.270^{* * *} \\
(18.80)\end{array}$ & $\begin{array}{l}0.291^{* * *} \\
(20.18)\end{array}$ \\
\hline Earnings Var & $\begin{array}{l}-1.447 \\
(-0.29)\end{array}$ & & $\begin{array}{c}-2.769^{* * *} \\
(-4.70)\end{array}$ & \\
\hline Diff Earnings Var & & $\begin{array}{l}-1.401 \\
(-0.13)\end{array}$ & & $\begin{array}{l}-1.884 \\
(-1.93)\end{array}$ \\
\hline Avg Earnings Var & & $\begin{array}{l}-1.479 \\
(-0.20)\end{array}$ & & $\begin{array}{c}-3.986^{* * *} \\
(-4.07)\end{array}$ \\
\hline Constant & $\begin{array}{c}405346.8^{*} \\
(2.07) \\
\end{array}$ & $\begin{array}{c}405331.7^{*} \\
(2.07) \\
\end{array}$ & $\begin{array}{c}314392.3^{* * *} \\
(5.23) \\
\end{array}$ & $\begin{array}{c}332056.5^{* * *} \\
(5.38) \\
\end{array}$ \\
\hline Observations & 1609 & 1609 & 14366 & 13397 \\
\hline
\end{tabular}


B. Men only

\begin{tabular}{|c|c|c|c|c|}
\hline & $\begin{array}{c}(1) \\
\text { MaleNM1 }\end{array}$ & $\begin{array}{c}(2) \\
\text { MaleNM2 }\end{array}$ & $\begin{array}{c}\text { (3) } \\
\text { MaleMar1 }\end{array}$ & $\begin{array}{c}\text { (4) } \\
\text { MaleMar2 }\end{array}$ \\
\hline Age & $\begin{array}{c}-15164.9 \\
(-1.30)\end{array}$ & $\begin{array}{c}-15054.4 \\
(-1.29)\end{array}$ & $\begin{array}{c}-16105.8^{* * * *} \\
(-3.49)\end{array}$ & $\begin{array}{c}-16726.5^{* * *} \\
(-3.57)\end{array}$ \\
\hline Age sq. & $\begin{array}{l}173.8 \\
(1.39)\end{array}$ & $\begin{array}{l}172.4 \\
(1.38)\end{array}$ & $\begin{array}{c}204.1^{* * *} \\
(4.12)\end{array}$ & $\begin{array}{c}210.1^{* * *} \\
(4.19)\end{array}$ \\
\hline Educ $<12$ th grade & $\begin{array}{c}-24410.6^{* * *} \\
(-4.15)\end{array}$ & $\begin{array}{c}-24319.3^{* * *} \\
(-4.13)\end{array}$ & $\begin{array}{c}-7496.6^{* *} \\
(-2.97)\end{array}$ & $\begin{array}{c}-6951.0^{* *} \\
(-2.67)\end{array}$ \\
\hline Educ $>12$ th grade & $\begin{array}{c}-4359.1 \\
(-1.06)\end{array}$ & $\begin{array}{c}-4232.1 \\
(-1.03)\end{array}$ & $\begin{array}{r}2744.5^{*} \\
(2.08)\end{array}$ & $\begin{array}{c}3025.3^{*} \\
(2.19)\end{array}$ \\
\hline 1990 Panel & $\begin{array}{c}-31807.2 \\
(-1.68)\end{array}$ & $\begin{array}{c}-32316.0 \\
(-1.70)\end{array}$ & $\begin{array}{c}-41809.4^{* * *} \\
(-5.66)\end{array}$ & $\begin{array}{c}-42708.6^{* * *} \\
(-5.58)\end{array}$ \\
\hline 1991 Panel & $\begin{array}{c}-17863.5 \\
(-0.91)\end{array}$ & $\begin{array}{c}-18182.9 \\
(-0.93)\end{array}$ & $\begin{array}{c}-37127.5^{* * *} \\
(-4.96)\end{array}$ & $\begin{array}{c}-37963.1^{* * *} \\
(-4.88)\end{array}$ \\
\hline 1992 Panel & $\begin{array}{c}-16853.6 \\
(-0.88)\end{array}$ & $\begin{array}{c}-17311.0 \\
(-0.90)\end{array}$ & $\begin{array}{c}-34443.8^{* * *} \\
(-4.61)\end{array}$ & $\begin{array}{c}-34811.8^{* * * *} \\
(-4.50)\end{array}$ \\
\hline 1993 Panel & $\begin{array}{c}-18757.6 \\
(-0.99)\end{array}$ & $\begin{array}{c}-19205.6 \\
(-1.01)\end{array}$ & $\begin{array}{c}-24668.5^{* * *} \\
(-3.32)\end{array}$ & $\begin{array}{c}-25346.2^{* *} \\
(-3.30)\end{array}$ \\
\hline 1996 Panel & $\begin{array}{c}-14964.6 \\
(-0.85)\end{array}$ & $\begin{array}{c}-15309.7 \\
(-0.87)\end{array}$ & $-19968.2^{* *}$ & $\begin{array}{c}-20498.3^{* *} \\
(-2.94)\end{array}$ \\
\hline Avg Earnings & $\begin{array}{c}0.521^{* * * *} \\
(5.61)\end{array}$ & $\begin{array}{c}0.514^{* * *} \\
(5.36)\end{array}$ & $\begin{array}{l}0.252^{* * *} \\
(13.02)\end{array}$ & $\begin{array}{l}0.261^{* * *} \\
(12.62)\end{array}$ \\
\hline Earnings Var & $\begin{array}{l}-7.459 \\
(-1.26)\end{array}$ & & $\begin{array}{l}-0.216 \\
(-0.25)\end{array}$ & \\
\hline Diff Earnings Var & & $\begin{array}{l}-10.82 \\
(-0.89)\end{array}$ & & $\begin{array}{l}-2.455 \\
(-1.81)\end{array}$ \\
\hline Avg Earnings Var & & $\begin{array}{l}-4.902 \\
(-0.68)\end{array}$ & & $\begin{array}{l}1.202 \\
(0.94)\end{array}$ \\
\hline Constant & $\begin{array}{c}406923.8 \\
(1.57)\end{array}$ & $\begin{array}{c}405058.7 \\
(1.57)\end{array}$ & $\begin{array}{c}429395.9^{* * *} \\
(4.21)\end{array}$ & $\begin{array}{c}445384.4^{* * *} \\
(4.31)\end{array}$ \\
\hline Observations & 740 & 740 & 7178 & 6684 \\
\hline
\end{tabular}


Table 5. Dependent variable Total per-capita Household Net Worth and Social Security Wealth, all SIPP Panels

\begin{tabular}{lcccc} 
A. All & \multicolumn{5}{c}{$(3)$} & $(4)$ \\
& NM1 & NM2 & Mar1 & Mar2 \\
\hline Age & -45222.6 & -45907.6 & $-17309.5^{*}$ & $-18041.6^{*}$ \\
& $(-1.30)$ & $(-1.33)$ & $(-2.14)$ & $(-2.12)$ \\
Age sq. & 566.9 & 572.5 & $266.1^{* *}$ & $273.7^{* *}$ \\
& $(1.38)$ & $(1.40)$ & $(3.08)$ & $(3.02)$ \\
Educ<12th grade & $-74478.2^{* * *}$ & $-73762.9^{* * *}$ & $-53005.6^{* * *}$ & $-51455.5^{* * *}$ \\
& $(-7.31)^{* * *}$ & $(-7.62)^{* * *}$ & $(-4.04)^{* *}$ & $(-3.51)$ \\
Educ>12th grade & $-40331.5^{* *}$ & $-38886.0^{* * *}$ & $-29272.7^{* *}$ & $-27606.8^{*}$ \\
& $(-4.32)$ & $(-4.09)$ & $(-2.62)$ & $(-2.24)$ \\
1990 Panel & 51389.9 & 49021.2 & $-96644.9^{*}$ & $-98424.4^{*}$ \\
& $(0.50)$ & $(0.48)$ & $(-2.42)$ & $(-2.31)$ \\
1991 Panel & 57447.5 & 57254.9 & $-99721.7^{*}$ & $-100555.2^{*}$ \\
& $(0.57)$ & $(0.57)$ & $(-2.49)$ & $(-2.34)$ \\
1992 Panel & 63588.3 & 61816.8 & $-95201.6^{*}$ & $-96589.2^{*}$ \\
& $(0.65)$ & $(0.63)$ & $(-2.35)$ & $(-2.23)$ \\
1993 Panel & 67869.3 & 66633.6 & $-85388.5^{*}$ & -86022.1 \\
& $(0.72)$ & $(0.70)$ & $(-2.08)$ & $(-1.95)$ \\
1996 Panel & 81754.2 & 81208.7 & -82146.8 & -85335.2 \\
& $(0.79)$ & $(0.78)$ & $(-1.95)$ & $(-1.89)$ \\
Female & -15661.0 & -14495.9 & $-35217.7^{* *}$ & $-36571.9^{* *}$ \\
& $(-1.17)$ & $(-1.05)$ & $(-3.04)$ & $(-2.98)$ \\
Avg Earnings & $2.454^{* * *}$ & $2.357^{* * *}$ & $0.676^{* * *}$ & $0.669^{* * *}$ \\
& $(3.88)$ & $(3.50)$ & $(5.51)$ & $(4.98)$ \\
Earnings Var & -17.14 & & $10.74^{* *}$ & \\
& $(-0.57)$ & & $(3.13)$ & \\
Diff Earnings Var & & -72.71 & & 0.469 \\
& & $(-1.81)$ & & $(0.08)$ \\
Avg Earnings Var & & 22.13 & & $18.92^{* *}$ \\
& & $(0.45)$ & $(3.03)$ \\
Constant & 930806.2 & 949320.7 & $491463.3^{* * *}$ & $510300.3^{* *}$ \\
& $(1.39)$ & $(1.43)$ & $(2.78)$ & $(2.84)$ \\
\hline Observations & 1609 & 1609 & 14366 & 13397 \\
\hline
\end{tabular}


B. Men only

\begin{tabular}{lcccc}
\hline & $(1)$ & $(2)$ & $(3)$ & $(4)$ \\
& MaleNM1 & MaleNM2 & MaleMar1 & MaleMar2 \\
\hline Age & -79961.7 & -76957.9 & -14652.6 & -14693.2 \\
& $(-1.22)$ & $(-1.13)$ & $(-1.33)$ & $(-1.20)$ \\
Age sq. & 1002.5 & 965.6 & $240.8^{*}$ & 240.9 \\
& $(1.29)$ & $(1.20)$ & $(2.08)$ & $(1.91)$ \\
Educ $<$ 12th grade & $-84327.2^{* * *}$ & $-81844.9^{* * *}$ & $-59411.5^{*}$ & $-59017.5^{*}$ \\
& $(-4.87)$ & $(-4.70)$ & $(-2.28)$ & $(-2.03)$ \\
Educ>12th grade & $-39914.8^{*}$ & $-36461.8^{*}$ & -37405.2 & -37116.6 \\
& $(-2.53)$ & $(-2.11)$ & $(-1.56)$ & $(-1.40)$ \\
1990 Panel & 212297.7 & 198466.1 & $-151512.3^{*}$ & $-158233.7^{*}$ \\
& $(1.12)$ & $(1.00)$ & $(-2.08)$ & $(-1.99)$ \\
1991 Panel & 203923.5 & 195241.8 & $-153360.2^{*}$ & $-159329.6^{*}$ \\
& $(1.08)$ & $(1.00)$ & $(-2.09)$ & $(-1.99)$ \\
1992 Panel & 215914.6 & 203478.8 & $-150278.1^{*}$ & -157206.4 \\
& $(1.17)$ & $(1.06)$ & $(-2.01)$ & $(-1.93)$ \\
1993 Panel & 215954.3 & 203775.6 & -138494.6 & -145227.8 \\
& $(1.20)$ & $(1.09)$ & $(-1.82)$ & $(-1.75)$ \\
1996 Panel & 240768.3 & 231386.5 & -132873.7 & -143155.8 \\
& $(1.15)$ & $(1.07)$ & $(-1.68)$ & $(-1.66)$ \\
Avg Earnings & $2.704^{*}$ & 2.509 & $0.531^{*}$ & 0.506 \\
& $(2.33)$ & $(1.95)$ & $(2.14)$ & $(1.79)$ \\
Earnings Var & -54.14 & & $12.15^{* *}$ & \\
& $(-0.81)$ & & $(3.16)$ & \\
Diff Earnings Var & & $-145.5^{*}$ & & 7.410 \\
& & $(-2.48)$ & & $(1.21)$ \\
Avg Earnings Var & & 15.36 & & $17.29^{*}$ \\
& & $(0.13)$ & & $(2.53)$ \\
Constant & 1435808.1 & 1385105.2 & 445508.8 & 454365.3 \\
& $(1.18)$ & $(1.11)$ & $(1.92)$ & $(1.87)$ \\
\hline Observations & 740 & 740 & 7178 & 6684 \\
\hline$t$ statistics in parentheses; $\left.{ }^{*} p<0.05{ }^{* *} p<0.01\right)^{* * *} p<0.001$ & \\
& & & &
\end{tabular}

The variance of earnings is highly skewed, and not independent of scale (so that correctly adjusting for inflation is a concern), but results not presented here using the standard deviation of earnings (the square root of variance), or the cube root of variance (which is more nearly normally distributed), or the coefficient of variation, produce qualitatively similar results. The distributions of dependent variables such as net worth are also highly skewed, and the distribution of residuals does not appear to be normal, but additional results not presented here using various transformations of the dependent variables also produce qualitatively similar results.

In additional estimates not presented here, we used an instrumental variables strategy to assess the impact on wealth of exogenous variation in earnings volatility due to state labor market conditions, and find similar results (in terms of sign and significance). Specifically, we instrument earnings volatility with different frequency 
components of variation in state unemployment rates over the prior year and a long-run difference and moving average over a five-year period prior to the survey. These instruments pass the usual tests of the validity of overidentification restrictions, absence of underidentification, and weak instruments (using a limited-information maximum likelihood approach due to the many excluded instruments) for regressions of wealth on earnings volatility. Specifications including both the moving average of earnings volatility and the first difference, however, do not pass the underidentification test, so we suspect that we can only identify exogenous movements in average volatility.

\section{Conclusions}

As policymakers try to address Social Security's unfunded obligation, now estimated at $\$ 4.3$ trillion over the 75-year projection horizon (Board of Trustees 2008), they should bear in mind the multiple roles that the program plays for American workers. The structure (e.g. progressive replacement rates) of Social Security provides insurance for lifetime income. However, we find that the impact of short-run earnings volatility on Social Security wealth is largely inconsequential.

At the same time, higher average levels of earnings volatility are associated with higher financial wealth and increases in earnings volatility are associated with lower financial wealth, suggesting precautionary saving and spend down of assets. Social Security seems to have a negligible insurance value with respect to earnings volatility, and even the small effects volatility has on Social Security wealth are often in the wrong direction to provide insurance, as higher earnings volatility is associated with lower Social Security wealth.

Neither average levels of earnings volatility nor increases in earnings volatility are randomly distributed in the population, so we cannot treat these associations as causal. Nevertheless, the impacts of earnings volatility on wealth measures in an instrumental variables approach are very similar to the point estimates presented here, suggesting that the bias from using observational data on households is not leading us to make incorrect inferences. Unfortunately, we cannot use that instrumental variables strategy to estimate the independent impacts of both short-run and long-run changes in volatility. 


\section{References:}

Acs, Gregory and Seth Zimmerman. 2008. “Like Watching Grass Grow? Assessing Changes in U.S. Economic Mobility over the Past Two Decades.” Economic Mobility Project of the Pew Charitable Trusts.

Baker, Michael, Dwayne Benjamin, and Shuchita Stanger. 1999. “The Highs and Lows of the Minimum Wage Effect: A Time-Series Cross-Section Study of the Canadian Law.” Journal of Labor Economics 17(2): 318-350.

Board of Trustees of the Federal Old-Age and Survivors Insurance and Disability Insurance [OASDI] Trust Funds. 2008. 2008 Annual Report of the Board of Trustees of the Federal Old-Age and Survivors Insurance and Disability Insurance Trust Funds. Washington, DC.

Committee on Ways and Means, United States House of Representatives. 2004. Overview of Entitlement Programs: 2004 Green Book Background Material and Data on Programs Within the Jurisdiction of the Committee on Ways and Means. Washington, DC: U.S. Government Printing Office.

Czajka, John L., James Mabli, and Scott Cody. 2007. Sample Loss and Survey Bias in Estimates of Social Security Beneficiaries: A Tale of Two Surveys. Final Report to the Social Security Administration. Washington, DC: Mathematica Policy Research, Inc.

CBO (Congressional Budget Office). 2007. "Trends in Earnings Variability Over the Past 20 Years.” Letter report to Charles E. Schumer and Jim Webb, April 17, written by Dahl, Molly, Thomas DeLeire, and Jonathan Schwabish.

CBO (Congressional Budget Office). 2008. "Recent Trends in the Variability of Individual Earnings and Household Income.” CBO Paper, June 30, written by Dahl, Molly, Thomas DeLeire, and Jonathan Schwabish.

Dynan, Karen, Douglas Elmendorf, and Daniel Sichel. “The Evolution of Household Income Volatility.” Finance and Economics Discussion Series 2007-61. Washington: Board of Governors of the Federal Reserve System, 2007.

Favreault, Melissa, Frank Sammartino, and C. Eugene Steuerle, ed. 2002. Social Security and the Family: Addressing Unmet Needs in an Underfunded System. Washington, DC: Urban Institute Press.

Gosselin, Peter G. 2004. “The Poor Have More Things Today -- Including Wild Income Swings.” Los Angeles Times. December 12 edition. [http://www.latimes.com/business/la-fi-poor12dec12,1,5929236.story]. 
Gosselin, Peter G. 2008. High Wire: The Precarious Financial Lives of American Families. New York: Basic Books.

Gottschalk, Peter, Robert Moffitt, Lawrence Katz, and William T. Dickens. 1994. "The Growth of Earnings Instability in the U.S. Labor Market.” Brookings Papers on Economic Activity, n(2): 217-272.

Hacker, Jacob. 2006. The Great Risk Shift. Oxford University Press.

Haider, Steven and Gary Solon. 2000. "Nonrandom Selection in the HRS Social Security Earnings Sample.” Working Paper No. 00-01, RAND Labor and Population Program. Available at: http://wwwpersonal.umich.edu/ gsolon/workingpapers/nonresp.pdf, accessed July 2007.

Hubbard R. Glenn. 1987. “Uncertain Lifetimes, Pensions, and Individual Saving," in Zvi Bodie, John B. Shoven, and David A. Wise (eds.), Issues in Pension Economics, Chicago: University of Chicago Press, pp. 175-205.

Hubbard R. Glenn. 1985. "Social Security, Liquidity Constraints, and Pre-Retirement Consumption,” Southern Economic Journal 51 (October): 471-484.

Hubbard, R. Glenn, Jonathan Skinner and Stephen P. Zeldes. 1995. "Precautionary Saving and Social Insurance,” Journal of Political Economy 105 (April): 360-399.

Hubbard, R. Glenn, Jonathan Skinner and Stephen P. Zeldes 1994. "Expanding the LifeCycle Model: Precautionary Saving and Public Policy.” American Economic Review 84 (May): 174-179.

Hubbard, R. Glenn and K. Judd. 1987. "Social Security and Individual Welfare: Precautionary Saving, Borrowing Constraints, and the Payroll Tax,” American Economic Review 77 (September): 630-646.

Johnson, Richard W., Gordon Mermin, and Dan Murphy. 2007. "The Impact of LateCareer Health and Employment Shocks on Social Security and Other Wealth.”

Juster, F. Thomas, James P. Smith, and Frank P. Stafford. 1999. "The Measurement and Structure of Household Wealth.” Labour Economics 6(2): 253-275.

Kapteyn, A., P.-C. Michaud, J. P. Smith, and A. Van Soest. 2006. "Effects of Attrition and Non-Response in the Health and Retirement Study.” Report to the Social Security Administration. RAND Corporation.

Mitchell, Olivia S., John Phillips, Andrew Au, and David McCarthy. 2007. "Lifetime Earnings Variability and Retirement Shortfalls." In Retirement Provision in Scary Markets, Ed. H. Bateman. Cheltenham, UK: Edward Elgar: 78-99. 
Moffitt, R.A. and Gottschalk, P. 2002. "Trends in the Transitory Variance of Earnings in the United States.” Economic Journal 112(3).

Nichols, Austin and Seth Zimmerman. 2008. "Measuring trends in the variability of income.” Washington, DC: The Urban Institute.

Parker, Simon with Tim Barmby and Yacine Belghitar. 2005. "Wage uncertainty and self-employed labour supply,” Economic Journal, Vol. 115, pp. C190-207.

St. Clair, Patricia, Darlene Blake, Delia Bugliari, Sandy Chien, Orla Hayden, Michael Hurd, Serhii Ilchuk, Fuan-Yue Kung, Angela Miu, Constantijn Panis, Philip Pantoja, Afshin Rastegar, Susann Rohwedder, Elizabeth Roth, Joanna Carroll, Julie Zissimopoulos. 2008. RAND HRS Data Documentation, Version H.

Smith, Karen E., Katherine Michelmore and Eric Toder. 2008. “Comparison of MINT 2003 and 2004 Projections with Survey Data.” Report to the Social Security Administration. Washington, DC: The Urban Institute.

Social Security Administration. 2008. Annual Statistical Supplement to the Social Security Bulletin. Washington, DC: Author.

Stapleton, David, Kevin Coleman, Kimberly Dietrich, and Gina Livermore. 1998. "Empirical Analyses of DI and SSI Application and Award Growth." In Kalman Rupp and David C. Stapleton, eds. Growth in Disability Benefits: Explanations and Policy Implications. Kalamazoo: Upjohn Institute. 


\section{Appendix A}

Table A1.

Percent Matched Rates, Survey data matched to Administrative Earnings Data, (Unweighted rates in parentheses)

\begin{tabular}{lccc}
\hline & $\begin{array}{l}\text { Overall match rate for } \\
\text { adults born between } \\
1935 \text { and 1956* }\end{array}$ & $\begin{array}{l}\text { Match rate for focal } \\
\text { group, 1943-1949* } \\
\text { birth cohorts }\end{array}$ & $\begin{array}{l}\text { Match rate spouses of } \\
\text { individuals in 1943- } \\
\text { 1949 cohorts, among } \\
\text { married persons }\end{array}$ \\
\hline \hline 1990 SIPP & $93(92)$ & $93(93)$ & $81(80)$ \\
1991 SIPP & $90(90)$ & $90(90)$ & $79(79)$ \\
1992 SIPP & $90(90)$ & $91(91)$ & $78(78)$ \\
1993 SIPP & $89(90)$ & $89(89)$ & $77(77)$ \\
1996 SIPP & $87(87)$ & $87(87)$ & $74(74)$ \\
2001 SIPP & $65(65)$ & $67(67)$ & $58(57)$ \\
2004 SIPP & $88(88)$ & $87(88)$ & $72(72)$ \\
1998 HRS & $78(80)$ & $71(72)$ & $64(64)$ \\
\hline
\end{tabular}

Source: Authors' calculations from the surveys matched to SER.

Notes: SIPP=Survey of Income and Program Participation; HRS= Health and Retirement Study. Detailed Earnings Records match rates are typically within a fraction of a percentage point of the Summary Earnings Record match rates.

* In the 1998 HRS sample, cohorts born in the 1931-1947 range only.

HRS includes both 2004 permissions administrative matches and initial match. 


\section{Appendix B. Health and Retirement Study Regression Results}

Appendix Table B1. 1998 HRS, Dependent Variable Household net worth A. All

\begin{tabular}{|c|c|c|c|c|}
\hline & $\begin{array}{c}(1) \\
\text { NM1 }\end{array}$ & $\begin{array}{c}(2) \\
\text { NM2 }\end{array}$ & $\begin{array}{c}(3) \\
\text { Mar1 }\end{array}$ & $\begin{array}{c}(4) \\
\text { Mar2 }\end{array}$ \\
\hline Age & $\begin{array}{c}-453164.4 \\
(-0.35)\end{array}$ & $\begin{array}{c}-621240.2 \\
(-0.49)\end{array}$ & $\begin{array}{c}878686.2 \\
(1.05)\end{array}$ & $\begin{array}{c}1034304.9 \\
(1.22)\end{array}$ \\
\hline Age squared & $\begin{array}{c}3983.8 \\
(0.33)\end{array}$ & $\begin{array}{c}5564.0 \\
(0.47)\end{array}$ & $\begin{array}{c}-8114.1 \\
(-1.01)\end{array}$ & $\begin{array}{c}-9624.2 \\
(-1.19)\end{array}$ \\
\hline Educ $<12$ th grade & $\begin{array}{c}-75329.2 \\
(-1.51)\end{array}$ & $\begin{array}{c}-79309.7 \\
(-1.50)\end{array}$ & $\begin{array}{c}-65232.8 \\
(-1.40)\end{array}$ & $\begin{array}{c}-88468.4 \\
(-1.94)\end{array}$ \\
\hline Educ $>12$ th grade & $\begin{array}{c}87087.3 \\
(1.14)\end{array}$ & $\begin{array}{c}79721.9 \\
(1.03)\end{array}$ & $\begin{array}{c}135867.7^{*} \\
(2.37)\end{array}$ & $\begin{array}{c}99641.6^{*} \\
(2.12)\end{array}$ \\
\hline Female & $\begin{array}{c}-100311.1 \\
(-1.19)\end{array}$ & $\begin{array}{c}-106135.1 \\
(-1.25)\end{array}$ & $\begin{array}{c}92791.3 \\
(1.83)\end{array}$ & $\begin{array}{c}57040.9 \\
(1.21)\end{array}$ \\
\hline Average earnings & $\begin{array}{l}-0.663 \\
(-0.60)\end{array}$ & $\begin{array}{l}-1.436 \\
(-0.64)\end{array}$ & $\begin{array}{c}3.126^{* *} \\
(2.91)\end{array}$ & $\begin{array}{l}1.381 \\
(1.41)\end{array}$ \\
\hline Earnings Var & $\begin{array}{l}779.2^{*} \\
(2.65)\end{array}$ & & $\begin{array}{l}28.74 \\
(0.70)\end{array}$ & \\
\hline Diff Earn Var & & $\begin{array}{l}559.1^{*} \\
(2.26)\end{array}$ & & $\begin{array}{l}-259.4 \\
(-1.84)\end{array}$ \\
\hline Avg Earn Var & & $\begin{array}{l}851.8 \\
(1.57)\end{array}$ & & $\begin{array}{c}301.0^{* *} \\
(2.68)\end{array}$ \\
\hline Constant & $\begin{array}{c}12959104.5 \\
(0.38)\end{array}$ & $\begin{array}{c}17433212.0 \\
(0.52)\end{array}$ & $\begin{array}{c}-23704933.0 \\
(-1.07)\end{array}$ & $\begin{array}{c}-27646860.3 \\
(-1.24)\end{array}$ \\
\hline Observations & 75 & 75 & 460 & 460 \\
\hline \multicolumn{5}{|l|}{ B. Men only } \\
\hline & $\begin{array}{c}1) \\
\text { MaleNM1 }\end{array}$ & $\begin{array}{c}(2) \\
\text { MaleNM2 }\end{array}$ & $\begin{array}{c}\text { (3) } \\
\text { MaleMar1 }\end{array}$ & $\begin{array}{c}(4) \\
\text { MaleMar2 }\end{array}$ \\
\hline Age & $\begin{array}{c}346607.8 \\
(0.28)\end{array}$ & $\begin{array}{c}-937178.6 \\
(-0.81)\end{array}$ & $\begin{array}{c}514879.4 \\
(0.47)\end{array}$ & $\begin{array}{c}523424.0 \\
(0.47)\end{array}$ \\
\hline Age squared & $\begin{array}{c}-3607.3 \\
(-0.30)\end{array}$ & $\begin{array}{c}8577.6 \\
(0.79)\end{array}$ & $\begin{array}{c}-4681.0 \\
(-0.45)\end{array}$ & $\begin{array}{c}-4826.7 \\
(-0.45)\end{array}$ \\
\hline Educ $<12$ th grade & $\begin{array}{c}-83132.8 \\
(-1.23)\end{array}$ & $\begin{array}{c}-53264.2 \\
(-1.31)\end{array}$ & $\begin{array}{c}-68289.1 \\
(-1.02)\end{array}$ & $\begin{array}{c}-72095.1 \\
(-1.11)\end{array}$ \\
\hline Educ $>12$ th grade & $\begin{array}{c}19261.0 \\
(0.21)\end{array}$ & $\begin{array}{c}43220.1 \\
(0.59)\end{array}$ & $\begin{array}{c}186232.6^{*} \\
(2.28)\end{array}$ & $\begin{array}{c}138680.5^{*} \\
(2.19)\end{array}$ \\
\hline Average earnings & $\begin{array}{l}-3.094 \\
(-1.73)\end{array}$ & $\begin{array}{l}-2.677 \\
(-1.24)\end{array}$ & $\begin{array}{l}2.844^{*} \\
(2.03)\end{array}$ & $\begin{array}{l}1.018 \\
(0.79)\end{array}$ \\
\hline Earnings Var & $\begin{array}{l}-96.99 \\
(-0.70)\end{array}$ & & $\begin{array}{l}21.89 \\
(0.55)\end{array}$ & \\
\hline Diff Earn Var & & $\begin{array}{l}-3263.7 \\
(-1.44)\end{array}$ & & $\begin{array}{l}-292.5 \\
(-1.82)\end{array}$ \\
\hline Avg Earn Var & & $\begin{array}{c}-1715.8 \\
(-1.35)\end{array}$ & & $\begin{array}{l}321.0^{*} \\
(2.46)\end{array}$ \\
\hline Constant & $\begin{array}{c}-8122604.1 \\
(-0.25)\end{array}$ & $\begin{array}{c}25639423.2 \\
(0.84)\end{array}$ & $\begin{array}{c}-13988046.3 \\
(-0.49)\end{array}$ & $\begin{array}{c}-14009509.2 \\
(-0.48)\end{array}$ \\
\hline Observations & 45 & 45 & 339 & 339 \\
\hline
\end{tabular}


Appendix Table B2. 1998 HRS, Dependent Variable Per-capita Household net worth A. All

\begin{tabular}{|c|c|c|c|c|}
\hline & $\begin{array}{c}(1) \\
\text { NM1 }\end{array}$ & $\begin{array}{c}(2) \\
\text { NM2 }\end{array}$ & $\begin{array}{c}\text { (3) } \\
\text { Mar1 }\end{array}$ & $\begin{array}{c}(4) \\
\text { Mar2 }\end{array}$ \\
\hline Age & $\begin{array}{c}-234753.6 \\
(-0.29)\end{array}$ & $\begin{array}{c}-306906.1 \\
(-0.38)\end{array}$ & $\begin{array}{c}282570.7 \\
(0.76)\end{array}$ & $\begin{array}{c}338948.6 \\
(0.90)\end{array}$ \\
\hline Age squared & $\begin{array}{c}2055.9 \\
(0.26)\end{array}$ & $\begin{array}{c}2734.2 \\
(0.36)\end{array}$ & $\begin{array}{c}-2535.7 \\
(-0.72)\end{array}$ & $\begin{array}{c}-3082.8 \\
(-0.86)\end{array}$ \\
\hline Educ $<12$ th grade & $\begin{array}{c}-50512.2 \\
(-2.01)\end{array}$ & $\begin{array}{c}-52221.0 \\
(-1.97)\end{array}$ & $\begin{array}{c}-38378.2 \\
(-1.85)\end{array}$ & $\begin{array}{c}-46796.1^{*} \\
(-2.23)\end{array}$ \\
\hline Educ $>12$ th grade & $\begin{array}{c}78023.7 \\
(1.92)\end{array}$ & $\begin{array}{c}74861.8 \\
(1.78)\end{array}$ & $\begin{array}{c}47879.9 \\
(1.85)\end{array}$ & $\begin{array}{c}34755.9 \\
(1.57)\end{array}$ \\
\hline Female & $\begin{array}{c}-36872.1 \\
(-0.97)\end{array}$ & $\begin{array}{c}-39372.2 \\
(-1.04)\end{array}$ & $\begin{array}{c}51384.1^{* *} \\
(2.63)\end{array}$ & $\begin{array}{c}38432.4^{*} \\
(2.01)\end{array}$ \\
\hline Average earnings & $\begin{array}{l}-0.693 \\
(-0.99)\end{array}$ & $\begin{array}{l}-1.025 \\
(-0.85)\end{array}$ & $\begin{array}{l}1.145^{*} \\
(2.34)\end{array}$ & $\begin{array}{c}0.513 \\
(0.95)\end{array}$ \\
\hline Earnings Var & $\begin{array}{l}356.5 \\
(1.89)\end{array}$ & & $\begin{array}{l}17.10 \\
(1.05)\end{array}$ & \\
\hline Diff Earn Var & & $\begin{array}{l}262.1 \\
(1.71)\end{array}$ & & $\begin{array}{l}-87.30 \\
(-1.53)\end{array}$ \\
\hline Avg Earn Var & & $\begin{array}{c}387.7 \\
(1.25)\end{array}$ & & $\begin{array}{l}115.7^{*} \\
(2.37)\end{array}$ \\
\hline Constant & $\begin{array}{c}6738984.5 \\
(0.31) \\
\end{array}$ & $\begin{array}{c}8659652.4 \\
(0.41) \\
\end{array}$ & $\begin{array}{c}-7824900.9 \\
(-0.81)\end{array}$ & $\begin{array}{c}-9252991.2 \\
(-0.94)\end{array}$ \\
\hline Observations & 75 & 75 & 460 & 460 \\
\hline \multicolumn{5}{|l|}{ B. Men only } \\
\hline & $\begin{array}{c}(1) \\
\text { MaleNM1 }\end{array}$ & $\begin{array}{c}(2) \\
\text { MaleNM2 }\end{array}$ & $\begin{array}{c}(3) \\
\text { MaleMar1 }\end{array}$ & $\begin{array}{c}(4) \\
\text { MaleMar2 }\end{array}$ \\
\hline Age & $\begin{array}{c}219460.7 \\
(0.25)\end{array}$ & $\begin{array}{c}-417886.0 \\
(-0.42)\end{array}$ & $\begin{array}{c}96595.6 \\
(0.19)\end{array}$ & $\begin{array}{c}99776.8 \\
(0.19)\end{array}$ \\
\hline Age squared & $\begin{array}{c}-2328.2 \\
(-0.28)\end{array}$ & $\begin{array}{c}3721.1 \\
(0.40)\end{array}$ & $\begin{array}{l}-756.9 \\
(-0.15)\end{array}$ & $\begin{array}{l}-811.2 \\
(-0.16)\end{array}$ \\
\hline Educ $<12$ th grade & $\begin{array}{c}-43298.1 \\
(-1.14)\end{array}$ & $\begin{array}{c}-28469.6 \\
(-1.02)\end{array}$ & $\begin{array}{c}-49123.8 \\
(-1.73)\end{array}$ & $\begin{array}{c}-50540.7 \\
(-1.83)\end{array}$ \\
\hline Educ $>12$ th grade & $\begin{array}{c}73329.1 \\
(1.04)\end{array}$ & $\begin{array}{c}85223.8 \\
(1.29)\end{array}$ & $\begin{array}{c}68000.4 \\
(1.76)\end{array}$ & $\begin{array}{c}50296.8 \\
(1.57)\end{array}$ \\
\hline Average earnings & $\begin{array}{l}-3.186 \\
(-1.83)\end{array}$ & $\begin{array}{l}-2.979 \\
(-1.62)\end{array}$ & $\begin{array}{l}0.922 \\
(1.50)\end{array}$ & $\begin{array}{l}0.243 \\
(0.36)\end{array}$ \\
\hline Earnings Var & $\begin{array}{l}-194.3 \\
(-1.51)\end{array}$ & & $\begin{array}{l}16.67 \\
(1.05)\end{array}$ & \\
\hline Diff Earn Var & & $\begin{array}{c}-1766.4 \\
(-1.60)\end{array}$ & & $\begin{array}{l}-100.4 \\
(-1.59)\end{array}$ \\
\hline Avg Earn Var & & $\begin{array}{l}-998.0 \\
(-1.60)\end{array}$ & & $\begin{array}{l}128.0^{*} \\
(2.30)\end{array}$ \\
\hline Constant & $\begin{array}{c}-5026284.8 \\
(-0.22)\end{array}$ & $\begin{array}{c}11735161.4 \\
(0.45)\end{array}$ & $\begin{array}{c}-2912793.4 \\
(-0.22)\end{array}$ & $\begin{array}{c}-2920784.0 \\
(-0.21)\end{array}$ \\
\hline Observations & 45 & 45 & 339 & 339 \\
\hline
\end{tabular}


Appendix Table B3. 1998 HRS, Dependent Variable Household net housing equity A. All

\begin{tabular}{lcccc}
\hline & $(1)$ & $(2)$ & $(3)$ & $(4)$ \\
& NM1 & NM2 & Mar1 & Mar2 \\
\hline Age & -322292.1 & -275915.2 & 162247.3 & 190937.7 \\
& $(-0.74)$ & $(-0.69)$ & $(0.67)$ & $(0.81)$ \\
Age squared & 3133.1 & 2697.1 & -1524.1 & -1802.5 \\
& $(0.76)$ & $(0.71)$ & $(-0.67)$ & $(-0.80)$ \\
Educ<12th grade & $-28717.6^{*}$ & $-27619.2^{*}$ & -383.5 & -4667.3 \\
& $(-2.34)$ & $(-2.16)$ & $(-0.03)$ & $(-0.31)$ \\
Educ >12th grade & $39318.8^{*}$ & $41351.1^{*}$ & $42382.4^{* *}$ & $35703.6^{*}$ \\
& $(2.21)$ & $(2.19)$ & $(2.88)$ & $(2.50)$ \\
Female & 3857.0 & 5464.0 & 13496.8 & 6905.7 \\
& $(0.21)$ & $(0.30)$ & $(1.19)$ & $(0.60)$ \\
Average earnings & 0.231 & 0.444 & $0.873^{*}$ & 0.551 \\
& $(0.97)$ & $(1.02)$ & $(2.55)$ & $(1.90)$ \\
Earnings Var & 64.66 & & $16.30^{*}$ & \\
& $(0.76)$ & & $(2.43)$ & \\
Diff Earn Var & & $125.4^{*}$ & & -36.83 \\
& & $(2.64)$ & & $(-1.47)$ \\
Avg Earn Var & & 44.60 & & $66.50^{* *}$ \\
& & $(0.53)$ & & $(3.30)$ \\
Constant & 8312986.7 & 7078451.9 & -4249614.8 & -4976364.2 \\
& $(0.73)$ & $(0.67)$ & $(-0.67)$ & $(-0.80)$ \\
\hline Observations & 75 & 75 & 460 & 460 \\
\hline
\end{tabular}

B. Men only

\begin{tabular}{|c|c|c|c|c|}
\hline & $\begin{array}{c}1) \\
\text { MaleNM1 }\end{array}$ & $\begin{array}{c}(2) \\
\text { MaleNM2 }\end{array}$ & $\begin{array}{c}\text { (3) } \\
\text { MaleMar1 }\end{array}$ & $\begin{array}{c}(4) \\
\text { MaleMar2 }\end{array}$ \\
\hline Age & $\begin{array}{c}-351914.9 \\
(-0.75)\end{array}$ & $\begin{array}{c}-319481.8 \\
(-0.64)\end{array}$ & $\begin{array}{c}411546.5 \\
(1.45)\end{array}$ & $\begin{array}{c}412767.4 \\
(1.45)\end{array}$ \\
\hline Age squared & $\begin{array}{c}3398.5 \\
(0.75)\end{array}$ & $\begin{array}{c}3090.7 \\
(0.65)\end{array}$ & $\begin{array}{c}-3915.1 \\
(-1.45)\end{array}$ & $\begin{array}{c}-3935.9 \\
(-1.46)\end{array}$ \\
\hline Educ $<12$ th grade & $\begin{array}{c}-27758.3 \\
(-1.56)\end{array}$ & $\begin{array}{c}-28512.9 \\
(-1.56)\end{array}$ & $\begin{array}{c}2435.1 \\
(0.15)\end{array}$ & $\begin{array}{c}1891.2 \\
(0.11)\end{array}$ \\
\hline Educ $>12$ th grade & $\begin{array}{c}38939.4 \\
(1.32)\end{array}$ & $\begin{array}{c}38334.1 \\
(1.29)\end{array}$ & $\begin{array}{c}53658.5^{* * *} \\
(3.70)\end{array}$ & $\begin{array}{c}46864.0^{* * * *} \\
(3.53)\end{array}$ \\
\hline Average earnings & $\begin{array}{c}-0.0966 \\
(-0.13)\end{array}$ & $\begin{array}{l}-0.107 \\
(-0.14)\end{array}$ & $\begin{array}{l}0.721^{*} \\
(2.17)\end{array}$ & $\begin{array}{c}0.460 \\
(1.53)\end{array}$ \\
\hline Earnings Var & $\begin{array}{l}-210.9 \\
(-1.73)\end{array}$ & & $\begin{array}{l}17.42^{*} \\
(2.48)\end{array}$ & \\
\hline Diff Earn Var & & $\begin{array}{l}-130.9 \\
(-0.26)\end{array}$ & & $\begin{array}{l}-27.51 \\
(-1.04)\end{array}$ \\
\hline Avg Earn Var & & $\begin{array}{l}-170.0 \\
(-0.61)\end{array}$ & & $\begin{array}{c}60.16^{* *} \\
(2.87)\end{array}$ \\
\hline Constant & $\begin{array}{c}9145771.6 \\
(0.74)\end{array}$ & $\begin{array}{c}8292821.0 \\
(0.63)\end{array}$ & $\begin{array}{c}-10726324.1 \\
(-1.44)\end{array}$ & $\begin{array}{c}-10729390.9 \\
(-1.44)\end{array}$ \\
\hline Observations & 45 & 45 & 339 & 339 \\
\hline
\end{tabular}


Appendix Table B4. 1998 HRS, Dependent Variable Social Security Wealth A. All

\begin{tabular}{|c|c|c|c|c|}
\hline & $\begin{array}{c}(1) \\
\text { NM1 }\end{array}$ & $\begin{array}{c}(2) \\
\text { NM2 }\end{array}$ & $\begin{array}{c}\text { (3) } \\
\text { Mar1 }\end{array}$ & $\begin{array}{c}(4) \\
\text { Mar2 }\end{array}$ \\
\hline Age & $\begin{array}{c}-287095.3 \\
(-1.10)\end{array}$ & $\begin{array}{c}-298251.3 \\
(-1.09)\end{array}$ & $\begin{array}{c}111988.4 \\
(1.26)\end{array}$ & $\begin{array}{c}113240.9 \\
(1.28)\end{array}$ \\
\hline Age squared & $\begin{array}{c}2796.2 \\
(1.12)\end{array}$ & $\begin{array}{c}2901.1 \\
(1.12)\end{array}$ & $\begin{array}{c}-1031.3 \\
(-1.22)\end{array}$ & $\begin{array}{c}-1043.3 \\
(-1.24)\end{array}$ \\
\hline Educ $<12$ th grade & $\begin{array}{c}-44060.5^{*} \\
(-2.51)\end{array}$ & $\begin{array}{c}-44301.6^{*} \\
(-2.51)\end{array}$ & $\begin{array}{c}-16964.3^{* *} \\
(-3.28)\end{array}$ & $\begin{array}{c}-17050.2^{* *} \\
(-3.29)\end{array}$ \\
\hline Educ $>12$ th grade & $\begin{array}{c}4907.2 \\
(0.44)\end{array}$ & $\begin{array}{c}4452.5 \\
(0.40)\end{array}$ & $\begin{array}{c}-8634.6^{*} \\
(-2.13)\end{array}$ & $\begin{array}{c}-8790.8^{*} \\
(-2.18)\end{array}$ \\
\hline Female & $\begin{array}{l}6022.9 \\
(0.60)\end{array}$ & $\begin{array}{l}5678.7 \\
(0.56)\end{array}$ & $\begin{array}{c}-12555.7^{*} \\
(-2.58)\end{array}$ & $\begin{array}{c}-12698.7^{*} \\
(-2.56)\end{array}$ \\
\hline Average earnings & $0.301^{* * *}$ & 0.257 & $\begin{array}{c}0.313^{* * *} \\
(568)\end{array}$ & $0.306^{* * *}$ \\
\hline Earnings Var & $\begin{array}{l}75.18^{*} \\
(2.41)\end{array}$ & & $\begin{array}{l}-2.277^{*} \\
(-2.01)\end{array}$ & \\
\hline Diff Earn Var & & $\begin{array}{l}62.73^{*} \\
(2.25)\end{array}$ & & $\begin{array}{l}-3.401 \\
(-0.88)\end{array}$ \\
\hline Avg Earn Var & & $\begin{array}{l}79.27^{*} \\
(2.30)\end{array}$ & & $\begin{array}{l}-1.215 \\
(-0.32)\end{array}$ \\
\hline Constant & $\begin{array}{c}7431171.6 \\
(1.08)\end{array}$ & $\begin{array}{c}7727951.7 \\
(1.08)\end{array}$ & $\begin{array}{c}-2934242.1 \\
(-1.25)\end{array}$ & $\begin{array}{c}-2966672.7 \\
(-1.27)\end{array}$ \\
\hline Observations & 72 & 72 & 451 & 451 \\
\hline \multicolumn{5}{|l|}{ B. Men only } \\
\hline & $\begin{array}{c}1) \\
\text { MaleNM1 } \\
\end{array}$ & $\begin{array}{c}(2) \\
\text { MaleNM2 } \\
\end{array}$ & $\begin{array}{c}\text { (3) } \\
\text { MaleMar1 } \\
\end{array}$ & $\begin{array}{c}(4) \\
\text { MaleMar2 } \\
\end{array}$ \\
\hline Age & $\begin{array}{c}-91524.0 \\
(-0.31)\end{array}$ & $\begin{array}{c}-191336.4 \\
(-0.54)\end{array}$ & $\begin{array}{c}13092.4 \\
(0.20)\end{array}$ & $\begin{array}{c}17135.3 \\
(0.26)\end{array}$ \\
\hline Age squared & $\begin{array}{l}955.4 \\
(0.34)\end{array}$ & $\begin{array}{c}1901.9 \\
(0.56)\end{array}$ & $\begin{array}{l}-107.8 \\
(-0.17)\end{array}$ & $\begin{array}{l}-146.8 \\
(-0.23)\end{array}$ \\
\hline Educ $<12$ th grade & $\begin{array}{c}-32865.9 \\
(-1.32)\end{array}$ & $\begin{array}{c}-31260.4 \\
(-1.21)\end{array}$ & $\begin{array}{c}-17013.6^{* * *} \\
(-3.72)\end{array}$ & $\begin{array}{c}-17057.5^{* * *} \\
(-3.73)\end{array}$ \\
\hline Educ $>12$ th grade & $\begin{array}{c}27638.5 \\
(1.53)\end{array}$ & $\begin{array}{c}28697.5 \\
(1.56)\end{array}$ & $\begin{array}{c}-3211.3 \\
(-0.79)\end{array}$ & $\begin{array}{c}-3898.0 \\
(-0.95)\end{array}$ \\
\hline Average earnings & $\begin{array}{l}0.430 \\
(1.43)\end{array}$ & $\begin{array}{l}0.462 \\
(1.41)\end{array}$ & $\begin{array}{c}0.249^{* * *} \\
(5.36)\end{array}$ & $\begin{array}{c}0.225^{* * *} \\
(4.43)\end{array}$ \\
\hline Earnings Var & $\begin{array}{l}77.01 \\
(1.36)\end{array}$ & & $\begin{array}{l}-2.097^{* * *} \\
(-3.13)\end{array}$ & \\
\hline Diff Earn Var & & $\begin{array}{l}-111.5 \\
(-0.69)\end{array}$ & & $\begin{array}{c}-6.276^{* *} \\
(-2.75)\end{array}$ \\
\hline Avg Earn Var & & $\begin{array}{l}-19.47 \\
(-0.21)\end{array}$ & & $\begin{array}{l}1.876 \\
(0.77)\end{array}$ \\
\hline Constant & $\begin{array}{c}2232661.7 \\
(0.29)\end{array}$ & $\begin{array}{c}4860631.4 \\
(0.52)\end{array}$ & $\begin{array}{c}-300838.3 \\
(-0.17)\end{array}$ & $\begin{array}{c}-405200.0 \\
(-0.23)\end{array}$ \\
\hline Observations & 42 & 42 & 336 & 336 \\
\hline
\end{tabular}


Appendix Table B5. 1998 HRS, Dependent Variable Net Worth plus Social Security Wealth A. All

\begin{tabular}{|c|c|c|c|c|}
\hline & $\begin{array}{c}(1) \\
\text { NM1 }\end{array}$ & $\begin{array}{c}(2) \\
\text { NM2 }\end{array}$ & $\begin{array}{c}\text { (3) } \\
\text { Mar1 }\end{array}$ & $\begin{array}{c}\text { (4) } \\
\text { Mar2 }\end{array}$ \\
\hline Age & $\begin{array}{c}-762128.5 \\
(-0.67)\end{array}$ & $\begin{array}{c}-856652.2 \\
(-0.77)\end{array}$ & $\begin{array}{c}410186.5 \\
(0.97)\end{array}$ & $\begin{array}{c}526269.4 \\
(1.21)\end{array}$ \\
\hline Age squared & $\begin{array}{c}7143.7 \\
(0.66)\end{array}$ & $\begin{array}{c}8032.7 \\
(0.76)\end{array}$ & $\begin{array}{c}-3715.0 \\
(-0.92)\end{array}$ & $\begin{array}{c}-4826.3 \\
(-1.17)\end{array}$ \\
\hline Educ $<12$ th grade & $\begin{array}{c}-98901.5^{* *} \\
(-3.15)\end{array}$ & $\begin{array}{c}-100943.9^{* *} \\
(-3.07)\end{array}$ & $\begin{array}{c}-56595.1^{*} \\
(-2.51)\end{array}$ & $\begin{array}{c}-64551.1^{* * *} \\
(-2.81)\end{array}$ \\
\hline Educ $>12$ th grade & $\begin{array}{c}82693.1 \\
(1.83)\end{array}$ & $\begin{array}{c}78840.6 \\
(1.68)\end{array}$ & $\begin{array}{c}43377.3 \\
(1.55)\end{array}$ & $\begin{array}{c}28898.3 \\
(1.19)\end{array}$ \\
\hline Female & $\begin{array}{c}-27199.3 \\
(-0.65)\end{array}$ & $\begin{array}{c}-30115.6 \\
(-0.72)\end{array}$ & $\begin{array}{c}37326.1 \\
(1.74)\end{array}$ & $\begin{array}{c}24075.4 \\
(1.12)\end{array}$ \\
\hline Average earnings & $\begin{array}{l}-0.404 \\
(-0.60)\end{array}$ & $\begin{array}{l}-0.771 \\
(-0.68)\end{array}$ & $\begin{array}{l}1.447^{* *} \\
(2.84)\end{array}$ & $\begin{array}{l}0.814 \\
(1.45)\end{array}$ \\
\hline Earnings Var & $\begin{array}{l}431.7^{*} \\
(2.44)\end{array}$ & & $\begin{array}{l}15.04 \\
(0.88)\end{array}$ & \\
\hline Diff Earn Var & & $\begin{array}{c}326.3 \\
(1.97)\end{array}$ & & $\begin{array}{l}-89.14 \\
(-1.52)\end{array}$ \\
\hline Avg Earn Var & & $\begin{array}{l}466.4 \\
(1.60)\end{array}$ & & $\begin{array}{l}113.5^{*} \\
(2.25)\end{array}$ \\
\hline Constant & $\begin{array}{c}20465339.1 \\
(0.68)\end{array}$ & $\begin{array}{c}22979920.7 \\
(0.78)\end{array}$ & $\begin{array}{c}-11169811.0 \\
(-1.01)\end{array}$ & $\begin{array}{c}-14175708.4 \\
(-1.25)\end{array}$ \\
\hline Observations & 72 & 72 & 451 & 451 \\
\hline \multicolumn{5}{|l|}{ B. Men only } \\
\hline & $\begin{array}{c}1) \\
\text { MaleNM1 } \\
\end{array}$ & $\begin{array}{c}(2) \\
\text { MaleNM2 } \\
\end{array}$ & $\begin{array}{c}(3) \\
\text { MaleMar1 } \\
\end{array}$ & $\begin{array}{c}(4) \\
\text { MaleMar2 } \\
\end{array}$ \\
\hline Age & $\begin{array}{c}-58831.4 \\
(-0.05)\end{array}$ & $\begin{array}{c}-1049751.0 \\
(-0.63)\end{array}$ & $\begin{array}{c}-10607.8 \\
(-0.02)\end{array}$ & $\begin{array}{c}105723.5 \\
(0.18)\end{array}$ \\
\hline Age squared & $\begin{array}{l}436.0 \\
(0.04)\end{array}$ & $\begin{array}{r}9832.7 \\
(0.63)\end{array}$ & $\begin{array}{l}265.9 \\
(0.05)\end{array}$ & $\begin{array}{l}-856.2 \\
(-0.15)\end{array}$ \\
\hline Educ $<12$ th grade & $\begin{array}{c}-81220.3 \\
(-1.66)\end{array}$ & $\begin{array}{c}-65281.9 \\
(-1.58)\end{array}$ & $\begin{array}{c}-65898.9^{*} \\
(-2.28)\end{array}$ & $\begin{array}{c}-67161.6^{*} \\
(-2.38)\end{array}$ \\
\hline Educ $>12$ th grade & $\begin{array}{c}106891.2 \\
(1.27)\end{array}$ & $\begin{array}{c}117404.4 \\
(1.50)\end{array}$ & $\begin{array}{c}69656.6 \\
(1.71)\end{array}$ & $\begin{array}{c}49897.0 \\
(1.47)\end{array}$ \\
\hline Average earnings & $\begin{array}{l}-2.800 \\
(-1.49)\end{array}$ & $\begin{array}{l}-2.486 \\
(-1.23)\end{array}$ & $\begin{array}{l}1.151 \\
(1.83)\end{array}$ & $\begin{array}{l}0.457 \\
(0.67)\end{array}$ \\
\hline Earnings Var & $\begin{array}{l}-143.9 \\
(-0.87)\end{array}$ & & $\begin{array}{l}14.78 \\
(0.90)\end{array}$ & \\
\hline Diff Earn Var & & $\begin{array}{c}-2015.5 \\
(-1.71)\end{array}$ & & $\begin{array}{l}-105.5 \\
(-1.65)\end{array}$ \\
\hline Avg Earn Var & & $\begin{array}{c}-1101.8 \\
(-1.68)\end{array}$ & & $\begin{array}{l}129.1^{*} \\
(2.30)\end{array}$ \\
\hline Constant & $\begin{array}{c}2025522.9 \\
(0.06)\end{array}$ & $\begin{array}{c}28115547.9 \\
(0.64) \\
\end{array}$ & $\begin{array}{c}-16294.3 \\
(-0.00)\end{array}$ & $\begin{array}{c}-3019259.6 \\
(-0.19)\end{array}$ \\
\hline Observations & 42 & 42 & 336 & 336 \\
\hline
\end{tabular}




\section{RECENT WORKING PAPERS FROM THE}

\section{CENTER FOR RETIREMENT RESEARCH AT BOSTON COLLEGE}

\section{The Housing Bubble and Retirement Security}

Alicia H. Munnell and Mauricio Soto, with the assistance of Jean-Pierre Aubry, August 2008

How Much Do State and Economic and Other Characteristics Affect Retirement Behavior?

Alicia H. Munnell, Mauricio Soto, Robert K. Triest, and Natalia A. Zhivan, August 2008

Will People Be Healthy Enough to Work Longer?

Alicia H. Munnell, Mauricio Soto, and Alex Golub-Sass, August 2008

An Assessment of Life-Cycle Funds

Mauricio Soto, Robert K. Triest, Alex Golub-Sass, and Francesca Golub-Sass, May 2008

Participant Perceptions and Decision-Making Concerning Retirement Benefits

Colleen E. Medill, February 2008

A Micro-Level Analysis of Recent Increases in Labor Participation Among Older Workers

Kevin E. Cahill, Michael D. Giandrea, and Joseph F. Quinn, February 2008

The Trajectory of Wealth in Retirement

David A. Love, Michael G. Palumbo, and Paul A. Smith, February 2008

The Rising Age at Retirement in Industrial Countries

Gary Burtless, February 2008

The Implications of Career Lengths for Social Security

Melissa M. Favreault and C. Eugene Steuerle, February 2008

Do Out-of-Pocket Health Care Costs Delay Retirement?

Richard W. Johnson, Rudolph G. Penner, and Desmond Toohey, February 2008

How the Income and Tax Treatment of Saving and Social Security Benefits May Affect Boomers' Retirement Incomes

Barbara A. Butrica, Karen E. Smith, and Eric J. Toder, February 2008

All working papers are available on the Center for Retirement Research website

(http://www.bc.edu/crr) and can be requested by e-mail (crr@bc.edu) or phone (617-552-1762). 